\title{
Human Induced Pluripotent Stem Cell as a Disease Modeling and Drug Development Platform-A Cardiac Perspective
}

\author{
Mohamed M. Bekhite*(D) and P. Christian Schulze \\ Department of Internal Medicine I, Division of Cardiology, University Hospital Jena, FSU, 07747 Jena, Germany; \\ Christian.Schulze@med.uni-jena.de \\ * Correspondence: Mohamed.el_Saied@med.uni-jena.de; Tel.: +49-3641-9325-813
}

Citation: Bekhite, M.M.; Schulze, P.C Human Induced Pluripotent Stem Cell as a Disease Modeling and Drug Development Platform-A Cardiac Perspective. Cells 2021, 10, 3483. https://doi.org/10.3390/cells10123483

Academic Editor: Andrea Pession

Received: 5 November 2021

Accepted: 6 December 2021

Published: 9 December 2021

Publisher's Note: MDPI stays neutral with regard to jurisdictional claims in published maps and institutional affiliations.

Copyright: (c) 2021 by the authors. Licensee MDPI, Basel, Switzerland. This article is an open access article distributed under the terms and conditions of the Creative Commons Attribution (CC BY) license (https:// creativecommons.org/licenses/by/ $4.0 /)$.

\begin{abstract}
A comprehensive understanding of the pathophysiology and cellular responses to drugs in human heart disease is limited by species differences between humans and experimental animals. In addition, isolation of human cardiomyocytes (CMs) is complicated because cells obtained by biopsy do not proliferate to provide sufficient numbers of cells for preclinical studies in vitro. Interestingly, the discovery of human-induced pluripotent stem cell (hiPSC) has opened up the possibility of generating and studying heart disease in a culture dish. The combination of reprogramming and genome editing technologies to generate a broad spectrum of human heart diseases in vitro offers a great opportunity to elucidate gene function and mechanisms. However, to exploit the potential applications of hiPSC-derived-CMs for drug testing and studying adult-onset cardiac disease, a full functional characterization of maturation and metabolic traits is required. In this review, we focus on methods to reprogram somatic cells into hiPSC and the solutions for overcome immaturity of the hiPSC-derived-CMs to mimic the structure and physiological properties of the adult human CMs to accurately model disease and test drug safety. Finally, we discuss how to improve the culture, differentiation, and purification of CMs to obtain sufficient numbers of desired types of hiPSC-derived-CMs for disease modeling and drug development platform.
\end{abstract}

Keywords: iPSC; cardiomyocytes; metabolic phenotype; genome-editing; disease modeling; drug testing

\section{Introduction}

Many cardiac diseases are characterized by functional and structural abnormalities that lead to myocyte death [1,2]. To this end, several in vivo and in vitro models have been established to investigate environmental factors for cardiomyopathies such as myocarditis, cardiotoxicity, and non-ischemic as well as genetic cardiomyopathies [3-8]. However, the lack of knowledge about the underlying causes and mechanisms of cardiomyopathy has been recognized. Therefore, a better understanding of the pathogenic mechanisms is crucial to capture the early stages of disease development and to develop sensitive and effective drugs with fewer side effects. Due to difficulties in obtaining human adult cardiomyocytes (CMs), primary cell lines (neonatal CMs and adult CMs) from rodent hearts [9,10], immortalized cell lines (H9C2) [11], ANT-T antigen [12], AT-1 cells [13], MC29 [14], HL -1 [15], and $\mathrm{AC} 16$ [16], as well as mice and rats have provided the model for basic research and pharmaceutical investigation of human heart disease $[5,6]$. However, primary cell lines and immortalized cell lines may have genetic and metabolic abnormalities due to their origin, resulting in misleading cellular responses to pathological stress. In addition, some cases of human genetic cardiomyopathies, such as the Tmem43 (Transmembrane protein 43) mutation in the nuclear lamina-associated protein genes, which causes arrhythmogenic cardiomyopathy (ACM) in several families, cannot be modeled with Tmem43 knock-in or knock-out mice [17-19]. Therefore, animal models can be misleading when studying human cardiomyopathies and they fail to translate mouse research findings to humans due to interspecies differences in physiological characteristics (i.e., heart size, heart rate, and 
ion channel contributions) [20]. In addition, animal models are still time-consuming and relatively expensive to create. In this complex scenario, many drugs that perform well in preclinical primary and immortalized cell lines and rodent studies fail in humans due to lack of safety and/or efficacy. To overcome these limitations, it is more attractive to use an appropriate human disease model in vitro. This has led to the creation of alternative models, such as CMs, which are derived from human-induced pluripotent cell (hiPSC) and have an unlimited source of human cardiac cells that can be used to study heart disease at the cellular level and test therapeutics compounds [21,22]. Further, hiPSC technology has shown great promise and offers the possibility of overcoming ethical and safety concerns that have arisen with the use of human embryonic stem cell (hESC) [23]. Importantly, the technology used to generate iPSC from diseased or healthy individuals carries the genome of an individual's cells and can be differentiated into a wide range of individual cells from the three germ layers (ectoderm, mesoderm, and endoderm) [24]. For this reason, these human disease models in the dish hold great promise for studying disease progression, which is not possible with cell lines and animal models. Furthermore, the ability of hiPSC to reflect patient pathophysiology has revolutionized the way we study cardiomyopathy [25]. They provide a powerful in vitro model system for disease modeling for genetic studies, high-throughput drug screening, prediction of toxic effects of drugs, personalized therapy, and potentially in vivo cell replacement therapy [25-27]. Therefore, iPSC represent a successful platform for disease modeling and drug discovery, even more, accurate than other in vitro cell line cultures and in vivo animal models [27]. This review summarizes the advantages and limitations of hiPSC-derived-CMs as an alternative to animal models and primary cells in modeling cardiac cell types and pursuing novel therapeutic strategies.

\section{Reprogramming Somatic Cells to iPSC}

HiPSCs are derived from reprogrammed terminally differentiated mature cells by overexpressing a series of specific transcription factors: Oct4 (octamer-binding transcription factor 4), Sox2 (sex-determining region Y-box 2), Klf4 (Kruppel-like factor 4), and c-Myc (cellular myelocytomatosis oncogene) to convert somatic cells into pluripotent cells [21]. Takahashi and Yamanaka reported the first successful reprogramming iPSC in 2006 from mouse embryonic fibroblasts by using a retroviral vector system [21]. This result was confirmed in 2007 by using human cells [28]. Yamanaka and colleagues had successfully reprogrammed adult human fibroblasts using OCT4, SOX2, KLF4, c-MYC (collectively referred as OSKM) factors with a retroviral system into hiPSC [28-30]. Thomson and colleagues also used OCT4 and SOX2, whereas replacing the other two with Nanog and Lin28 using a lentiviral system method [31].

The OSKM transcription factors work together and lead to modulating the efficiency of reprogramming by inactivating the somatic program and activating the pluripotency program. c-Myc and Klf4 act as pioneer factors as they can induce two properties at the earliest stage of the reprogramming process: first, the opening and activation of condensed heterochromatin to form a euchromatin conformation; second, the binding to different sites in the genome and the recruitment of enzymes for histone modification (acetyltransferases and demethylases) [30]. Interestingly, it was found that exogenous c-Myc is not necessary for the reprogramming of mouse and human fibroblasts to iPSC as they express c-Myc and Klf4 [29]. However, the efficiency of reprogramming is much lower and requires more time [29,32]. Moreover, c-Myc has been found to induce apoptosis and senescence, and this effect can be abolished by Klf4 [33]. Upon completion of global chromatin remodeling, exogenous Oct 4 and Sox 2 are now able to positively activate the Oct4, Sox2, and Nanog genes, leading to a revival of the autoregulatory loop that triggers the pluripotency network and represses differentiation genes [34]. Oct3/4 is considered a key pluripotency factor and likely alters the cell fate of tumor cells to ESC [29]. It was found that Klf4 can be replaced with Klf2 or Klf5 and Sox 2 can be replaced with Sox1 or Sox3 [35]. The expression of OSKM factors in reprogrammed mouse fibroblasts requires only one week, whereas reprogrammed human fibroblasts require two weeks. During this 
period, the reprogrammed cells proliferate slowly and exhibit an incomplete/intermediate reprogrammed pluripotent state [36,37]. Most somatic cells have been shown to allow reprogramming to iPSC, including fibroblasts, peripheral blood mononuclear cells (PBMCs) such as $\mathrm{T}$ cells and endothelial progenitor cells (EPCs), cultured hair follicle-derived keratinocytes, urine-derived renal tubule cells, intestinal cells, adipose stromal cells, and others cells (Figure 1) [38-46]. An important recent development in this field has been the ability to perform reprogramming on PBMC, which have become the most commonly used cells for hiPSC reprogramming because blood samples are easy to obtain compared to fibroblasts from a skin punch biopsy [38,39,41]. In addition, isolating PBMCs is safe for the donor and not as costly as performing a skin biopsy.

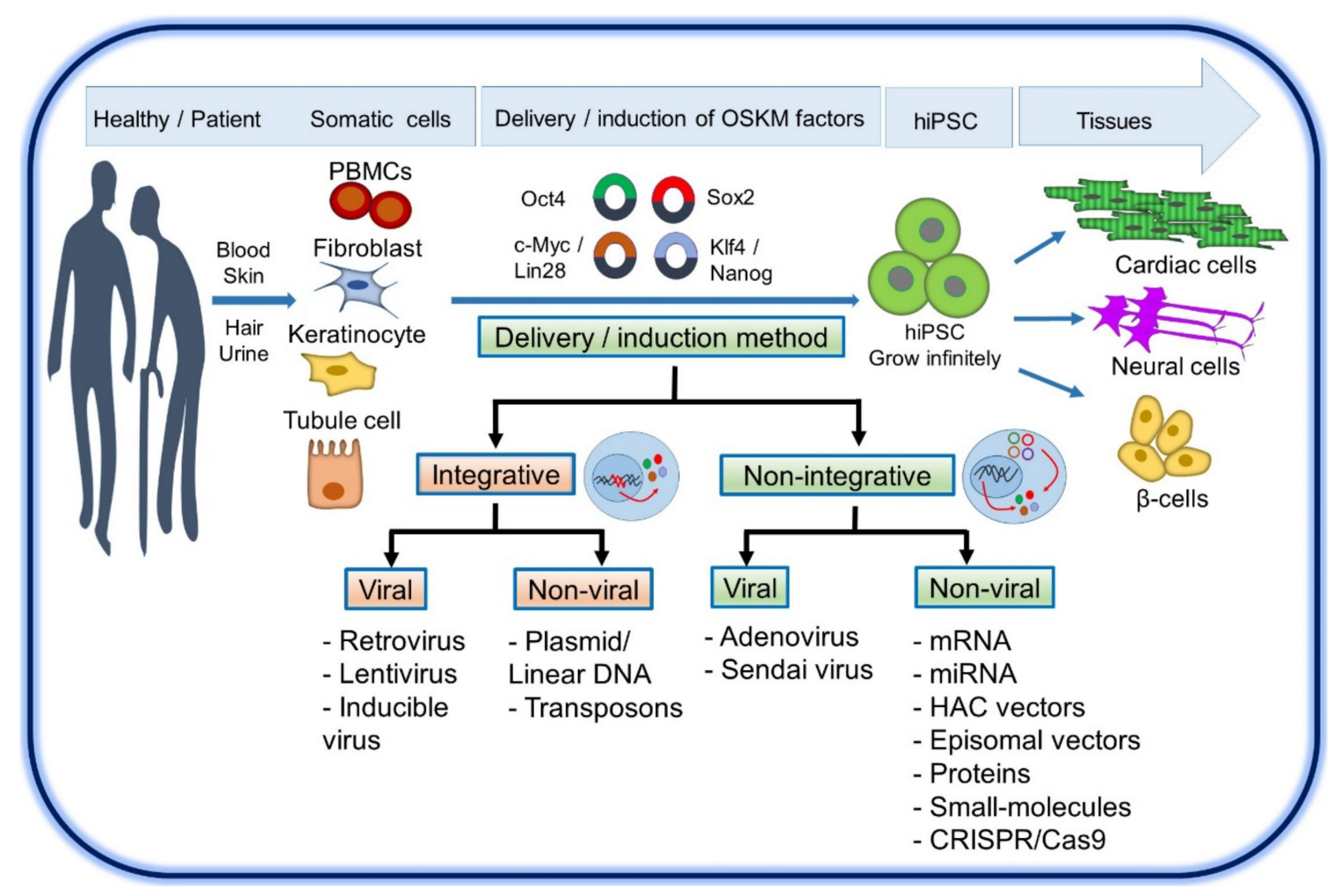

Figure 1. Schematic representation of delivery or induction of OSKM factors to convert somatic cells into pluripotent cells and differentiation the iPSC into a wide range of individual cells from the three germ layers.

\section{Delivery or Induction Methods of OSKM Factors}

Several delivery methods have been developed to improve the efficiency of iPSC reprogramming and reduce the risk of genomic insertion and mutagenesis [47]. Therefore, non-integrative delivery methods have been developed to overcome safety issues. Delivery methods can be divided into two categories: integrative methods, which are technically simple and have high efficiency, and non-integrative methods, which are technically relatively difficult and have low efficiency. Integrative methods include viral vector-based methods (retrovirus, lentivirus, and inducible virus) and non-viral vector methods (plasmid or linear DNA and transposons). Non-integrative viruses include viral (adenovirus and Sendai virus) [48], and nonviral vectors (episomal DNA vectors, RNAs, human artificial chromosomes (HAC), proteins, and small-molecule compounds) [49-52]. Integrative systems have been criticized because their vectors are integrated into the host genome, resulting in difficult differentiation of iPSC and posing a risk of insertional mutagenesis during transfection [29]. Sendai virus methods remain the most popular among researchers because they are effective in fibroblasts and PBMC and do not enter the nucleus of host cells $[38,48,53-56]$. In addition, vectors based on the Sendai virus have a replication 
deficiency that is lost after temperature-shift treatment or about 10 passages of newly obtained iPSC [53].

To generate iPSCs that are free from viral contamination, and also non-integrative systems, considerable progress has been made by transfecting DNA into cells using liposomes or electroporation, such as plasmids, episomal plasmids [57-62], minicircle DNA [63,64], removable piggyBac transposon followed by Cre transfection [65] and non-DNA based methods such as synthetic mRNAs [66,67], miRNAs (miR302/367 cluster) $[68,69]$ and recombinant proteins $[49,70]$. Although proteins or mRNAs can generate iPSC, the protocols are costly and technically challenging. However, this approach is considered less mutagenic than DNA-based approaches and non-integrative approaches. Recently, the CRISPR (Clustered Regular Interspaced Short Palindromic Repeats)-associated Cas9 nuclease (CRISPR/Cas9) system was developed and used to reprogram human skin fibroblasts into iPSC [71,72]. This technique uses a fusion protein of the enzymatically inactive form of Cas9 (dCas9) that retains a specific binding ability to DNA without causing DNA doublestrand breaks (DSBs) [73]. Moreover, a fusion of dCas9 with transcriptional activators allowed activation of the desired DNA locus with high specificity and efficiency with minimal off-target activity [74,75].

In summary, integrative methods and viral vector-based methods are not suitable for clinical application due to the risk of insertional mutagenesis, and non-viral, nonintegrative systems are more likely to be used for clinical application of hiPSC generated, which are maintained under feeder- and xeno-free culture conditions.

\section{Derivation of CMs Subtypes}

In the past decades, only primary CMs isolated from rodent hearts (1 5 day old rats or mice) and cardiac murine atrial myocytes (HL-1) cell line have been used as beating CMs for functional analyses of cardiomyopathies $[10,15,76,77]$. However, HL-1 cells and primary CMs have different electrophysiology and cannot recapitulate the entire pathophysiological profile of human heart disease $[15,78]$. Moreover, obtaining CMs from human hearts for functional analysis and genetic studies in patients is a highly invasive procedure and impossible in most cases. Moreover, the low proliferative capacity of CMs limits their long-term culture. The generation of patient-specific hiPSC-derived-CMs overcomes this problem and provides a promising cell source for understanding the pathological mechanism and developing new therapeutic agents.

Since inherited arrhythmias and cardiomyopathies affect different cardiac chambers, it is necessary to develop different protocols to generate atrial, ventricular, and pacemakerlike CMs subtypes. With the discovery of hiPSC, protocols for robust CMs differentiation from hiPSC have improved over the past decade [22,79-81]. The differentiation of iPSC into $\mathrm{CMs}$ is a complex and multistep process, so small variations at each step can lead to different results. Most protocols for differentiation of $\mathrm{CMs}$ use small molecule compounds and chemically defined media [82-84]. The small molecule glycogen synthase kinase (GSK)-3b inhibitor CHIR99021 is used to promote differentiation of iPSC into Brachyury-expressing mesodermal lineages, followed by treatment with the canonical Wnt inhibitor IWR-1, IWP2, XAV939, or Wnt-C59, which promotes differentiation of these mesodermal cells into the Nkx2.5 expressing cardiac progenitor cells $[85,86]$. Interestingly, recent studies have described that cardiac progenitor cells efficiently generate atrial-like (myosin light chain 2 atrial isoform, Mlc2a) in the presence of retinoic acid and ventricular-like (myosin light chain 2 ventricular isoform, Mlc2v) CMs in the absence of retinoic acid [87-89]. Generation of sinoatrial node (SAN) pacemaker cells (hyperpolarization-activated cyclic nucleotide channel 4, Hcn4) from hiPSC was achieved through activation of BMP and retinoic acid signaling pathways as well as overexpression of TBX3 [90,91]. Moreover, inhibition of Neregulin1 $\beta /$ ErbB signaling can lead to a three-fold increase in SAN pacemaker cell differentiation from hESCs [92]. In these protocols, it was found that various recombinant growth factors, e.g., BMP4, can also be used to increase the efficiency of iPSC differentiation in CMs $[85,91,93]$. 
All of these CMs subtypes have well-defined electrophysiological properties and gene expression profiles [94] as studied by patch-clamp technology [95], single-cell RNA sequencing [96], and voltage and calcium imaging [97]. In addition, many protocols have been established to differentiate the iPSC into nonmyocyte cell populations of the heart, such as epicardial cells [98], cardiac progenitor cells [99], cardiac fibroblasts [100,101], and valve interstitial cells [102]. Further, to generate vascular smooth muscle cells (vSMCs) or endothelial cells (ECs) as vascular cell types, vascular mesodermal progenitors lineages were first induced from iPSC, then by treatment with platelet-derived growth factor (PDGF)-BB, activin A and transforming growth factor (TGF)-b1 to induce lineage-specific vSMCs [103,104] with vascular endothelial growth factor (VEGF)-A to induce ECs [104,105].

Despite these advances in differentiating CMs with currently available protocols, it is desirable to obtain pure CMs to improve the efficiency and clinical compatibility. One strategy is to use fluorescence-activated cell sorting or magnetically activated cell sorting to separate CMs from other cells $[106,107]$. An ideal approach is to use lentiviral vectors to introduce antibiotic resistance genes driven by CM-specific promoters in hPSCs, which resulted in $96 \%$ pure CMs $[108,109]$. Another important step forward was the development of a protocol to purify hPSCs-CMs to $99 \%$ purity using glucose depletion and lactate supplementation [110]. However, obtaining a pure population of cell subtypes is a challenge that remains to be solved [92]. These improvements will be of great benefit not only for disease model research and drug development and screening but also for potential clinical application approaches.

\section{Challenges in iPSC-Derived-CMs Maturation}

To achieve more accurate disease modeling and maximize the potential applications of hiPSC-derived-CMs for drug testing, characterization of the maturation features of CMs is critical. Some features can be used to estimate the maturation of CMs, such as cell shape, sarcomere, composition of myofibrillar isoforms, T-tubules, mitochondria, metabolic substrate, number of nuclei, electrophysiological properties, calcium handling, contractile force, gap junction distribution, and response to $\beta$-adrenergic stimulation (Table 1) [111-115].

Table 1. Summary of the differences between immature and mature CMs.

\begin{tabular}{|c|c|c|}
\hline Parameter & Immature CMs & Mature CMs \\
\hline Cell shape & Irregular & Rod-shaped \\
\hline Cell area & $480 \pm 32 \mu \mathrm{m}^{2}$ & $1716 \pm 150 \mu \mathrm{m}^{2}$ \\
\hline Sarcomere structure & Disorganized and less-developed & Organized and M-line developed \\
\hline Sarcomere length & $\approx 1.65 \mu \mathrm{m}$ & $\approx 1.81-2.3 \mu \mathrm{m}$ \\
\hline Cardiac troponin I & ssTnI & cTnI \\
\hline Titin & N2BA isoform (N2B and N2A) & N2B \\
\hline MHC & $\beta-\mathrm{MHC} \leq \alpha-\mathrm{MHC}$ & $\beta-\mathrm{MHC}>>\alpha-\mathrm{MHC}$ \\
\hline T-tubules & Deficient & Abundant \\
\hline Mitochondria & Round and cristae are less mature & $\begin{array}{c}\text { Elongated and more mature cristae (up to } 40 \% \\
\text { cell volume) }\end{array}$ \\
\hline Sarcoplasmic reticulum network & Underdeveloped & Well-developed \\
\hline Metabolic & Glycolysis $(80 \%)$ & Fatty acid $\beta$-oxidation $70-80 \%$ ) \\
\hline Nucleation & Mononuclear & Dinuclear $(\sim 35.3 \%)$ \\
\hline Upstroke velocity & $\approx 44$ to $50 \mathrm{~V} / \mathrm{s}$ & $\approx 188.7$ to $250 \mathrm{~V} / \mathrm{s}$ \\
\hline Resting membrane potential & $\approx-50$ to $-60 \mathrm{mV}$ & $\approx-90 \mathrm{mV}$ \\
\hline Gap junction & Circumferentially & Periphery at the intercalated disc \\
\hline Adrenergic receptors & $\approx \beta 1 \leq \beta 2$ & $\begin{array}{c}\approx 70 \beta 1: 30 \beta 2 \text { and response to } \beta \text {-adrenergic } \\
\text { stimulation }\end{array}$ \\
\hline SERCA2a & Low expressed & Highly expressed \\
\hline Contraction & Asynchronous & Synchronous \\
\hline
\end{tabular}


It is known that human CMs require years to reach their adult phenotype in vivo [116-118]. Beating CMs can be generated from hiPSC within 6-8 days after differentiation [79,84]. However, iPSC-derived-CMs still have a circular/irregular shape that resembles the structure of immature human CMs, rather than the shape of rods like mature CMs [113,119]. In addition, these cells have a cell surface area $480 \pm 32 \mu \mathrm{m} 2$ compared to mature CMs, which have a cell area of about $1716 \pm 150 \mu \mathrm{m} 2$ and a diameter of 15-30 $\mu \mathrm{m}$ [120]. Furthermore, mature CMs were shown to have a sarcomere length of about $\approx 1.81-2.3 \mu \mathrm{m}$ compared to $\approx 1.65 \pm 0.02 \mu \mathrm{m}$ in immature CMs [121,122], and the structure of sarcomeres in mature CMs is highly organized, and the Z-bands run parallel to the intercalation disk [115,123]. Further, the gap junction proteins connexin 43 (Cx43) and N-cadherin are increasingly concentrated in the intercalation disks at the ends of the mature $\mathrm{CM}$, whereas they are circumferentially distributed in the immature CMs (Figure 2) [124]. Therefore, assessment of myofibrillar isoforms of proteins such as cardiac troponin I (ssTnI in immature CMs and cTnI in mature CMs) $[125,126]$, titin (N2BA in immature CMs and N2B in mature CMs), and the ratio of myosin heavy chain (MHC) ( $\beta-\mathrm{MHC}>>\alpha-\mathrm{MHC}$ in mature $\mathrm{CMs})$ may provide useful information about the maturation of hiPSC-derived-CMs [127]. Another factor that can assess CMs maturation is the increase in sarcoplasmic/endoplasmic reticulum $\mathrm{Ca}^{2+}$ ATPase (SERCA) and the ratio of $\beta 1$ to $\beta 2$ adrenergic receptors $(\approx 70 \beta 1: 30 \beta 2)$ in mature CMs [128-130]. In addition, membrane potential in ventricular immature CMs $(\approx-50$ to $-60 \mathrm{mV})$ compared to ventricular mature CMs $(\approx-90 \mathrm{mV})[115,123,131]$. Moreover, the values of the Nav1.5 sodium channel increase in mature CMs for upstroke velocity $(\approx 44$ to $50 \mathrm{~V} / \mathrm{s}$ in immature CMs and $\approx 188.7$ to $250 \mathrm{~V} / \mathrm{s}$ in mature CMs) [121,131,132]. In adult CMs, the sarcolemmal voltage gated L-type $\mathrm{Ca}^{2+}$ channels are located at the t-tubule network close to the sarcoplasmic reticulum (SR), which leads to synchronize release of $\mathrm{Ca}^{2+}$ from SR via ryanodine receptors (RyRs) in a rapid way during an action potential [133]. While undeveloped SR has been reported in immature hiPSC-derived-CMs, that is, express lower SERCA and cardiac SR luminal auxiliary proteins (calsequestrin, junctin, and triadin), which form a protein complex associated with RyR2 [134]. Also, SR is mainly distributed in the perinuclear region $[135,136]$. Furthermore, immature hiPSC-derived-CMs lack t-tubule network $[137,138]$. This results in poor co-localization of $\mathrm{Ca}^{2+}$ channels and RyRs, which contribute to unsynchronized and slow kinetics of the $\mathrm{Ca}^{2+}$ transients, which contribute to unsynchronized and slow kinetics of the $\mathrm{Ca}^{2+}$ transients $[135,139]$. 
(a)

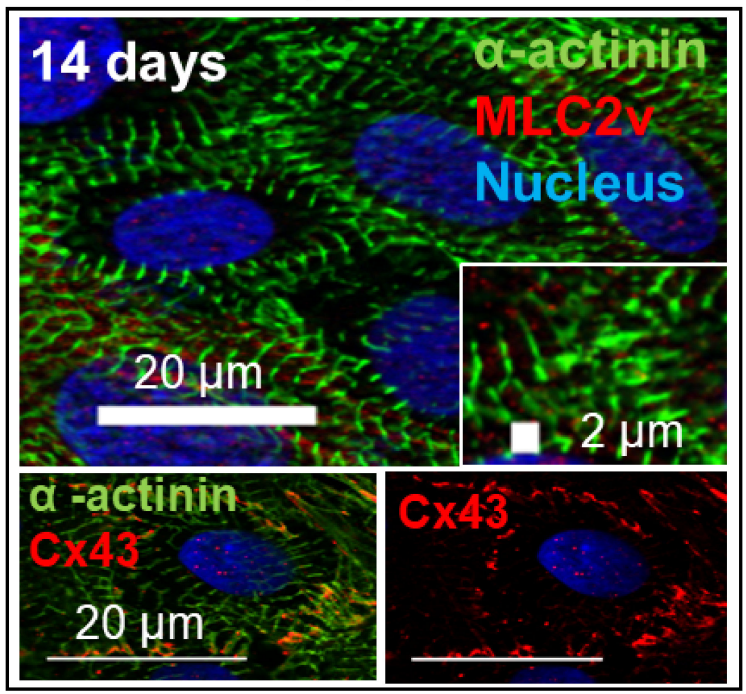

(c)

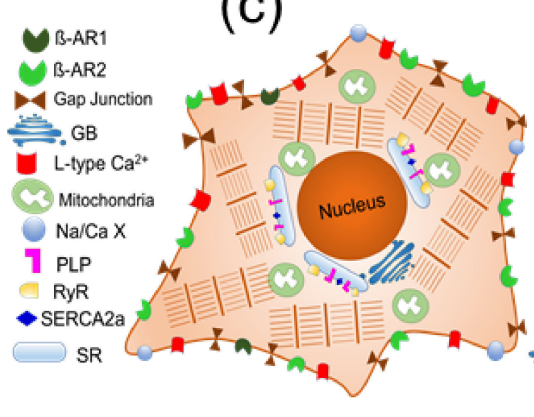

(d)

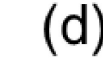

(b)

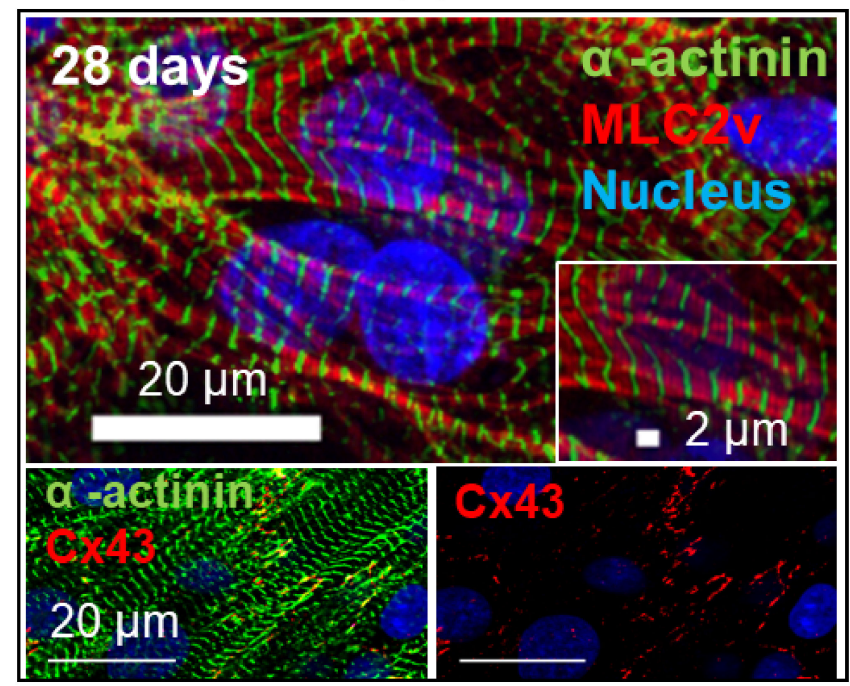

T-tubule

\section{-tubule}


suggest that the high activity of oxidative phosphorylation correlates with mitochondrial elongation and is consistent with the hypothesis that elongated mitochondria and their networks are more efficient at producing energy and can distribute energy over long distances $[113,151]$. In addition, mitochondrial maturity has been found to correlate with energy metabolism and ATP demand of mature hiPSC-derived-CMs. These important differences should be taken into account when using hiPSC-derived-CMs. Further studies on the maturation of iPSC-derived-CMs are needed in the future to develop optimal methods for more efficient differentiation of CMs that have the typical structure and physiological properties of adult CMs.

(a)

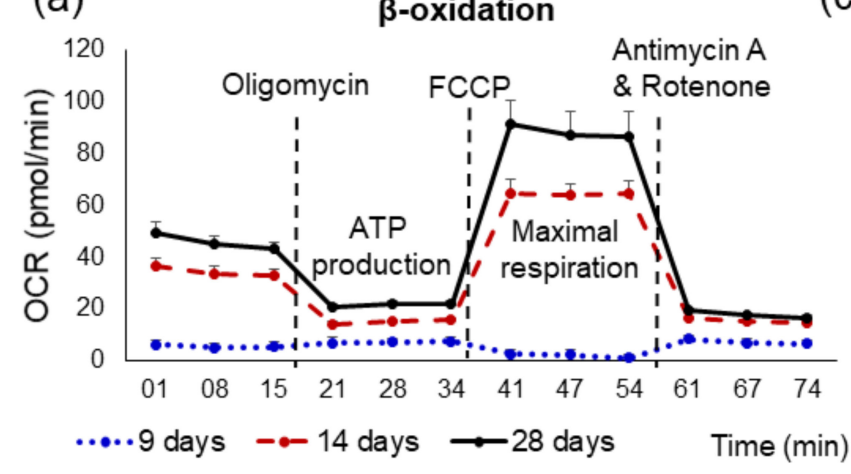

(c)

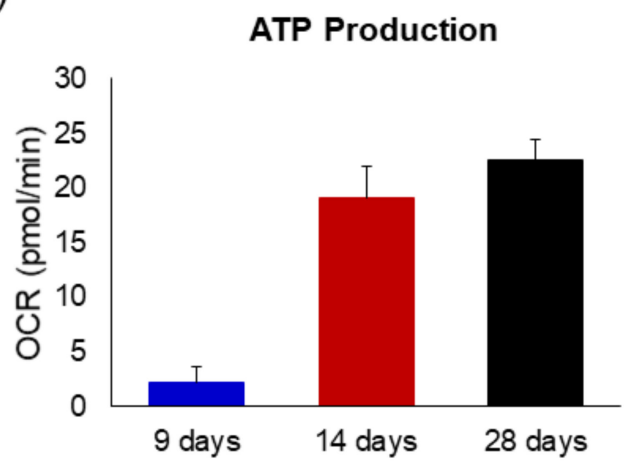

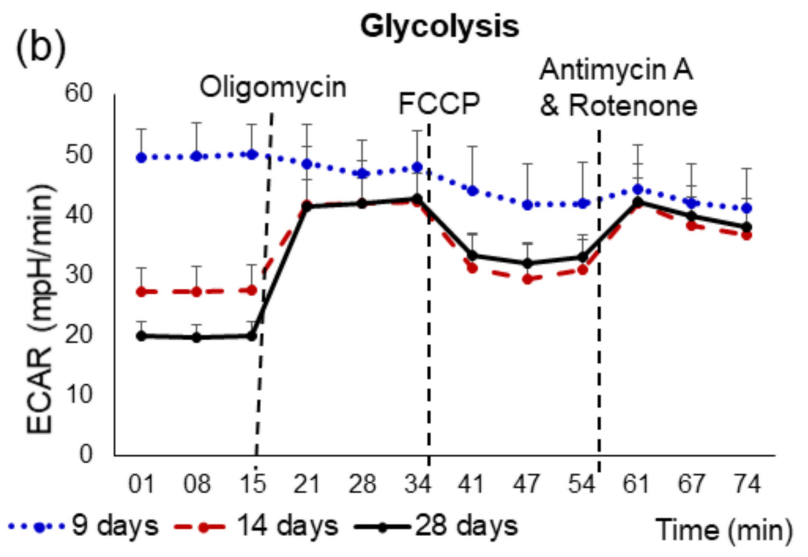

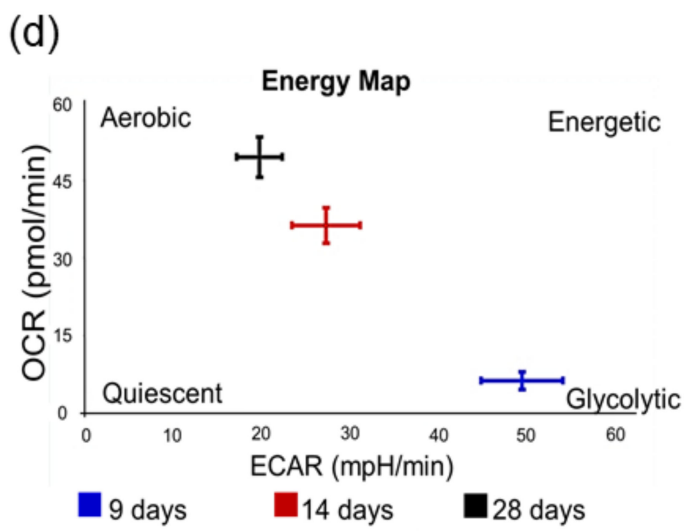

Figure 3. Analysis of CMs oxidative metabolism using a Seahorse XFe96 Analyzer to examine changes in metabolic profiles of hiPSC-derived-CMs following 9, 14, and 28 days of differentiation. The oxidative phosphorylation and glycolysis in CMs were measured through OCR (a) and ECAR (b), respectively. CM respiration was assayed under basal conditions and after addition of electron transport chain inhibitors, which were mitochondrial inhibitor oligomycin $(2 \mu \mathrm{M})$, mitochondrial uncoupler carbonylcyanide p-trifluoromethoxyphenylhydrazone (FCCP; $0.3 \mu \mathrm{M})$ as well as a respiratory chain inhibitor antimycin $\mathrm{A}(0.5 \mu \mathrm{M})$ and rotenone $(0.5 \mu \mathrm{M})$. (c) The averaged levels of ATP production. (d) Analysis of cell energy phenotype at 9 days hiPSC-derived-CMs were glycolysis-dependent and this is followed by a shift to $\beta$-oxidation metabolism at 14 and 28 day old CMs. These results indicate that a change in the cellular energy phenotype is accompanied by increasing the rate of $\mathrm{O}_{2}$ consumption and ATP synthesis to fulfill the needs of mature CMs.

\section{Applications of Genome Editing Technology in hiPSC}

Recently, the application of genome editing in hiPSC has been widely associated. Their combination can further enhance the power of hiPSC in pathophysiology study, drug screening, and new drug development [152,153]. Recent genome editing techniques can be divided into three main tools: zinc finger nucleases (ZFNs) [154,155], transcription activator-like effector nucleases (TALENs) [156] and CRISPR/Cas9 can be used to exchange relevant nucleotides at specific positions $[157,158]$. The three genome editing techniques that are used have a similar mechanism and are based on an endonuclease activity that 
specifically makes DSBs in DNA at desired locations in the genome. The DSB triggers DNA repair via two different pathways, homology-directed repair (HDR) or non-homologous end joining (NHEJ) [159-161]. In contrast to ZFNs and TALENs, CRISPR/Cas9 targets a specific genomic site using the protospacer motif (PAM) and single-guide RNA (sgRNA or gRNA) to induce a DSB complementary to the CRISPR sequence [159,162]. Furthermore, modifications to the catalytic site of the Cas9 nuclease enabled the generation of dead Cas9 (dCas9) fused to a deaminase (e.g., adenine or cytidine), allowing the conversion of guanine-cytosine pairs to adenine-thymine or vice versa, which enabled the development of single base editing without a DSB $[74,163,164]$. In this regard, CRISPR-Cas9 has become the standard technology for precise genome manipulation by providing genome editing, epigenetic modulation, and transcriptional control.

Analysis of disease-specific hiPSC-derived-CMs compared to wild-type hiPSC-derivedCMs prepared from healthy donor cells as controls can lead to unreliable results because the genetic and epigenetic background of the cells is largely unknown $[165,166]$. Even when control cells from non-diseased individuals in the same family (first-degree relatives) are used, the patients from whom the disease cells are derived share only $\approx 50 \%$ of the genome [166-168]. The importance of having an isogenic cell line increases the chance of identifying the role of a particular mutation in the disease and circumventing heterogeneity between patients [169]. CRISPR/Cas9 technology could serve as a tool to correct pathogenic gene mutations in disease-specific hiPSC and can also be applied to wild-type hiPSC to generate the specific mutation [170]. Thus, this technology can be used to generate isogenic control iPSC so that disease-specific hiPSC-derived-CMs and control iPSC-derived-CMs share the same genetic background and differ only at the mutation site to allow more accurate disease modeling [171,172].

\section{Strategies for Generating hiPSC for Heart Disease Modeling}

Methods for modeling hiPSC diseases generally rely on either hiPSC reprogrammed from patient-derived cells from mutation carriers or genetically engineered wild-type hiPSC using genome editing approaches such as CRISPR/Cas9, ZFN, and TALEN [152,171-175]. In addition to genome editing approaches, iPSCs or the differentiated CMs can be genetically modified by reducing the expression of specific mutant proteins, e.g., by RNA interference (Figure 4) [176].

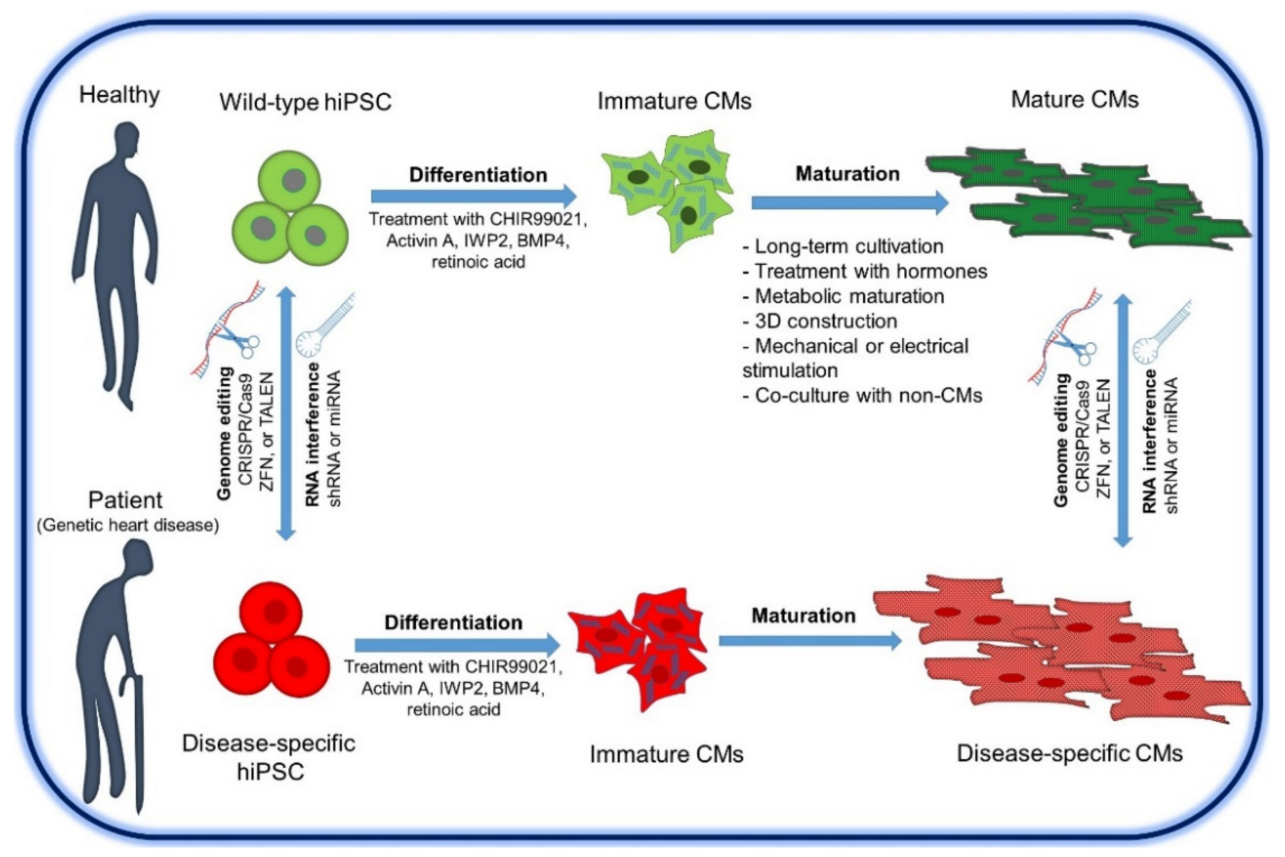

Figure 4. Summary of the strategies for generating hiPSC for heart disease modeling and protocols to 
improve the maturation of hiPSC-derived-CMs. Abbreviation: Clustered Regular Interspaced Short Palindromic Repeats-associated Cas9 nuclease, (CRISPR/Cas9); transcription activator-like effector nucleases (TALENs); Zinc finger nucleases, (ZFNs).

One of the major causes of heart disease is various genetic mutations. However, different mutations in the same gene may have different mechanisms at the molecular level but lead to similar clinical outcomes of heart disease [177,178]. Advances in patientspecific hiPSC-derived-CMs research have provided a platform to effectively study patientand disease-specific heart disease in vitro [179-181]. Moreover, these cells have recapitulated cellular electrophysiological changes in the heart of patients [182,183]. The use of patient-specific hiPSC-derived-CMs may be useful for basic science investigations as well as for patient-specific therapeutic screening and personalization of therapy. In 2010, Carvajal-Vergara and coworkers obtained iPSC carrying the heterozygous mutation of the PTPN11 gene from patients with leopard syndrome, which is often associated with severe hypertrophic cardiomyopathy (HCM) [184,185]. Interestingly, these iPSC-derived-CMs showed abnormal size and nuclear localization [184]. Since then, many different iPSC lines have been generated. In addition to modeling genetic cardiomyopathies, iPSC-derivedCMs have also been used to model environmental factors that cause cardiomyopathies, such as the cardiotoxicity of anticancer drugs [186], nonischemic cardiomyopathies [187], peripartum [188], and diabetic cardiomyopathy [189-192], or even infection with Coxsackie B3 virus [193] or parasitic flagellate protozoa [194].

Looking at the literature in previous years, the most common genetic heart disease analyzed is the various types of Long QT Syndrome (LQTS) mutations [195-200]. LQTS is one of the most common types of cardiac channelopathies and is due to delayed repolarization in the ventricular phase, which can lead to sudden cardiac death [201]. The hiPSC-derived-CMs carrying this mutation were used for functional analysis and showed a prolonged QT interval [202]. Patient-derived iPSC-derived-CMs carrying mutations of the alpha subunit of the voltage-gated potassium channel subfamily Q member 1 (KCNQ1; also known as KvLQT1 or Kv7.1) showed impaired membrane trafficking of slow IKs channels and cause LQT1 $[203,204]$. Itzhaki et al. obtained LQT2 hiPSC-derived-CMs carrying a mutation in the alpha subunit of the voltage-gated potassium channel subfamily $\mathrm{H}$, member 2 (KCNH2), which encodes the $\alpha$-subunit of the Kv11.1 channel (human ether-a-go-go-related gene; $\mathrm{hERG}$ ) responsible for conducting the fast delayed rectifier potassium current (IKr) in CMs [205]. In addition, in vitro models of disease-specific hiPSCderived-CMs were generated from patients with Timothy syndrome (LQT8), which leads to cardiac arrhythmias caused by a mutation in the subunit of the voltage-gated calcium channel alpha1 C (CACNA1C; responsible for the L-type calcium current, ICa,L) [206]. Interestingly, in another model, a cyclin-dependent kinase 5 (CDK5) was identified as a regulator of L-type $\mathrm{Ca}^{2+}$ channel function. Inhibition of $\mathrm{CDK} 5$ with roscovitine was able to rescue the phenotypes in iPSC-derived-CMs from Timothy syndrome patients [207].

In addition, other disease-specific hiPSC-derived-CMs have also been produced for inherited arrhythmias, including various types of LQTS mutations, including, potassium channel inwardly rectifying channel subfamily J member 2 (KCNJ2) [208], calmodulin 1 (CALM1), or calmodulin 2 (CALM2) [209,210], sodium channel protein type 5 subunit alpha (SCN5A; Brugada syndrome type 1) [211,212]. Another channelopathy that has been used to generate a disease model is catecholaminergic polymorphic ventricular tachycardia (CPVT). Sasaki et al. generated CMs from CPVT patient-derived iPSC and identified S107 as a potential therapeutic agent because preincubation with $\mathrm{S} 107$ resulted in a reduction in isoprenaline-induced delayed after depolarizations [213].

Several other studies have generated iPSCs-derived-CMs models associated with HCM. HCM is characterized by hypertrophy of the ventricular walls and/or septum, resulting in decreased cardiac output [214]. Many studies have examined CMs derived from HCM patient iPSC with mutations in genes encoding sarcomeric proteins or other mutations identified in patients with HCM, such as ACTC1 (cardiac actin) [215], ALPK3 ( $\alpha$-kinase 3) [216], BRAF (B-Raf proto-oncogene, serine/threonine kinase) [217], FBN1 
(Fibrillin 1; Marfan syndrome) [218], FXN (Frataxin; Friedreich ataxia) [219], GLA (Galactosidase $\alpha$; Fabry disease) [220]. MT-RNR2 (Mitochondrially encoded 16S rRNA) [221], MYBPC3 (Myosin binding protein C3) [222-231], MYH7 ( $\beta$-myosin heavy chain) [232-237], MYL2 (Myosin light chain 2) [238], MYL3 (Myosin light chain 3) [239], PRGAG2 (Protein kinase AMP-activated non-catalytic subunit gamma 2; Wolff-Parkinson-White Syndrome) [240,241], PTPN11 (Protein tyrosine phosphatase non-receptor type 11) [184,242]. RAF1 (Noonan syndrome) [242], SCO2 (Cytochrome c oxidase assembly protein) [243], TNNT2 (Cardiac troponin T) [222,244], and TPM1 (Tropomyosin-1) [228,229]. Interestingly, these mutant hiPSCs-derived-CMs were larger and exhibited a higher frequency of sarcomere disorganization. These cells also recapitulated abnormal calcium handling and exhibited abnormal electrophysiological and/or contraction measurements [245].

In addition to inherited cardiac arrhythmias, dilated cardiomyopathy (DCM) is one of the most important forms of cardiomyopathy [246]. DCM is manifested by enlargement of the left ventricle in combination with decreased ventricular thickness and heart failure due to severely impaired ejection fraction [247,248]. Based on family history and clinical findings, previous clinical studies have suggested that the most common mutated gene in familial DCM cases is Titin [249], followed by LMNA (lamin A/C) [250], MYH7 and MYH6 [251], SCN5A [252], MYBPC3 (Myosin-binding protein c, cardiac type) [253], and TNNT2 [254]. Interestingly, several known hiPSC-derived-CMs have been established to study inherited DCM, including desmin (DES) [255], function-related protein (FKRP) [256], LMNA [257-261], phospholamban (PLN) [262-265], RNA binding motif protein 20 (RBM20) [266,267], TNNT2 [128,244,262,268,269], Titin [269-271]. Patient-specific hiPSCs were produced from diseased members and CMs were generated and examined. After prolonged culture, the resulting CMs showed sarcomere disarray, defects in $\mathrm{Ca}^{2+}$ handling, and decreased contractility $[268,272]$. Sarcomere disarray was ameliorated by the addition of metoprolol and $\beta$-adrenergic blocker. In addition, decreased contractility could be enhanced by adenoviral overexpression of SERCA2a [268].

In addition, Sato $\mathrm{Y}$ et al., previously developed a model for late-onset of Pompe disease-hiPSC, an autosomal inherited metabolic disorder caused by a mutation in acid alpha-glucosidase (GAA). Interestingly, patient-specific hiPSC-derived-CMs exhibited higher levels of glycogen, mitochondrial dysfunction, and disordered CM fibers observed in the typical features of Pompe disease cardiomyopathy [273]. Although numerous studies have investigated the pathophysiology of heart disease using patient-specific hiPSCderived-CMs, it is still challenging to fully recapitulate the disease phenotype, as the use of hiPSC-derived-CMs can lead to controversial results, especially when studying late-onset heart disease due to the immaturity of hiPSC-derived-CMs for disease modeling [274-276].

\section{Consideration of hiPSC for Use in Modeling Heart Disease}

Despite the extensive advantages of hiPSC-derived-CMs model as a platform for heart disease research and development of new therapeutic agents, however, there are still unresolved issues related to the maturation of hiPSC-derived-CMs that pose an obstacle to adult cardiovascular disease modeling. To overcome these limitations, several studies have contributed to the development of protocols to improve the maturation of hiPSCderived-CMs (Figure 4). One method is to extend the duration of hiPSC-derived-CMs culture to more than 4 weeks [113]. In addition, culturing iPSC-derived-CMs for 3-7 days in a fatty acid-based medium improved the maturation of hiPSC-derived-CMs and showed significant changes in various aspects such as cell size, cell morphology, sarcomere length, gene and protein expression, metabolic changes, and percentage of multinucleate CMs, as well as an increase in calcium release and reuptake rates $[113,277,278]$. In addition, many laboratories are currently attempting to accelerate the maturation of CMs by treating CMs with triiodothyronine (T3) or dexamethasone (DEX), electrical or mechanical impulses, and culturing CMs in three-dimensional (3D) systems without/with scaffold materials [279-285]. However, the human native myocardium exhibits additional structural and functional complexity in terms of complex cell-extracellular matrix (ECM), cell-cell, 
and tissue-level interactions that are poorly represented by $2 \mathrm{D}$ cellular in vitro models. In this context, the recapitulation of native cardiac tissue structures and physiological function in vitro can be achieved by using 3D cellular constructs as new-generation models, which could improve the recapitulation of cardiac physiology and pathophysiology. Various types of 3D constructs have been produced by combining hiPSC-derived-CMs with non-cardiac cell types found in the heart, such as cardiac fibroblasts, endothelial cells, smooth muscle cells, and immune cells, in ratios similar to those found in the human heart [286,287]. 3D constructs of the human heart have been made with different compositions and architectures to reproduce cardiac spheroids (using non-adhesive U-shaped wells, hanging drops, or stirred cultures), artificial heart tissue, organoids, and heart-on-chip models [288-290]. However, organoid models of heart cultures still lack the vascularization that supplies oxygen and nutrients to the muscle [291]. The lack of oxygen and nutrients leads to the formation of a necrotic core [291]. However, the ever-growing field of organoid or gastruloids and artificial cardiac tissue technology, which offers a considerable number of features through the formation of small size organoids or the development of vascularization to solve this problem, will lead to a better understanding of disease pathogenesis at the tissue and organ level [288,292,293]. Recently, human cardiac organoids were used for modeling most of the cardiovascular diseases, which mimic the tissue architecture of heart, including cardiomyocytes, endothelial, stromal cells, and epicardial cells in vivo [122,294-296]. Further, many studies focus on vascularization of the cardiac organoids to overcome the lack of oxygen and nutrient diffusion, by coating the organoids with an extracellular matrix containing endothelial cells [297], cultured cardiac organoids with hPSC-derived endothelial cells [298], and fusion of two subregional organoids to form a complete organ [299]. Moreover, cardiac tissue engineering field has rapidly evolved over the past decade and offers a biomedicine discipline attempting to combine scaffolding polymers with cardiovascular cells to create cardiac tissue-like structures for drug screening, disease modeling, and cardiac repair [300-305]. Interestingly, the use of heart-on-a-chip models has recently increased, providing a controllable tool, mean oxygen delivery [306-309], pH [308], shear stress with a certain flow rate of the culture medium [310,311], temperature control, and electrical or mechanical stimulation, as well as continuous monitoring and measurement of parameters of the physiological responses of the cells. Unlike cardiac spheroids, cardiac patches can be seeded into a scaffold to form a layer $(4 \times 4 \mathrm{~cm})$ of CMs or together with other cells without losing functional properties [312,313]. However, cell sheet layering methods still have some limitations, mainly related to the number of cell layers before necrosis of the grafted patch occurs after its implantation. By using hiPSC-derived-CMs and endothelial cells encapsulated in tissue-based hydrogels using a 3D printing method, vascularized, thick $(2-7 \mathrm{~mm})$ cardiac patches could be fabricated that exhibit cell viability and contractility [314].

However, despite the promising results of preclinical research, further studies are needed to develop effective and more efficient strategies for cardiac regeneration in vivo. Finally, it should be considered that the use of hiPSC-derived-CMs could provide basic information about the pathology and pathophysiology of the heart, and thus is valuable for understanding the inherited disease, efficient drug testing, and the drug development process.

\section{Drug Testing and Drugs Development Using hiPSC-Derived-CMs}

Currently, the development of new drugs is expensive and requires many years of preclinical research with in vitro and in vivo testing as well as human clinical trials before they are allowed to reach the market [315]. In most cases, only a small fraction of safe drug candidates reach the market after years of multiple processes [316,317]. Many drugs have been withdrawn from the market despite passing in vivo and clinical tests. An example of this is the increased risk of QT prolongation of heart rate and ventricular arrhythmias, which was a factor in one-third of drugs withdrawn from the market due to safety concerns [318-321]. This may be due to differences between experimental animals and humans, such as the expression profile of ion channels and the physiological properties 
of heart rate ( 10-fold in mice at rest), which limit the utility of mice to study the effects of antiarrhythmic drugs [322]. As a result, researchers often turn to immortalized cell lines such as HL-1 cells due to the difficulties in obtaining and maintaining human primary cardiac cells. These challenges significantly slow the progress in drug development. Recently, researchers have turned to hiPSC-derived-CMs as an excellent alternative and a more reliable tool in the earliest stages of drug development to detect side effects of a new potential therapeutic agent that may cause prolongation of the QT interval before it is used in animal studies and clinical trials [323]. In addition, hiPSC allows us to study the behavior of ion channels in real CMs rather than in cell lines that are not myocytes and overexpress the potassium channel because of the response to compounds tested with hiPSC-derived-CMs in vitro is similar to that of the human body [324]. The effects of new drugs can be assessed in several ways, including electrophysiological responses using microelectrode arrays (MEAs), patch-clamp, or $\mathrm{Ca}^{2+}$ oscillation measurements. Their thorough analysis allows determining whether a particular drug blocks or activates one of the ion channels involved in action potential generation [325-327]. In addition, hiPSC-derivedCMs provide a higher safety model for preclinical testing to verify the cardiotoxicity of the human-specific response, which is a common reason for withdrawal of drugs from marketing or rejection in the final stages of clinical trials. Blockade of the ion channel encoded by the hERG has been associated with prolongation of the QT interval, which in turn is correlated with cardiac arrest and death from torsades de pointes (TdP) [328]. The study of hERG activity using patch-clamp currents in the absence and presence of a drug is now commonly part of safety pharmacological risk assessment [329]. In previous study, iPSC-derived-CMs were used to test 31 inotropic and 20 non-inotropic compounds previously characterized for their effects on contraction changes in CMs and were found to have a specificity of $70 \%$ and a sensitivity of $87 \%$ [330]. This shows that iPSC-derived-CMs can be used for cardiotoxicity screening [331]. Another study by researchers at the US Food and Drug Administration confirmed the potential use of iPSC-derived-CMs for predicting drug risk for cardiac arrhythmias [332]. Because iPSC-derived-CMs have a significant advantage as a system for testing potential drug candidates, they are beginning to be used in drug discovery research. For example, to overcome the high toxicity of doxorubicin, hiPSC-derived-CMs have been used to test a liposomal formulation of doxorubicin that resulted in little or no uptake into human CMs and prevented the signs of cardiotoxicity. These results support the clinical decision to move into Phase I clinical trials with the drug formulation [333].

HiPSC-derived-CMs can also serve as models for potential drugs development against heart disease (see the review by Hnatiuk et al.) [334]. Interestingly, Leonid Maizels and co-workers investigated the drug response in a disease-specific hiPSCs-derived-CMs model of the autosomal recessive form of catecholaminergic polymorphic ventricular tachycardia type 2 (CPVT2) (because of the D307H-CASQ2 mutation). The authors found that flecainide application has protective against the development of arrhythmias in the CPVT2hiPSC-derived-CMs, which correlates with clinical data collected from the same cell donor patient [335]. In a recent study by Knottnerus et al., accumulation of long-chain fatty acid oxidation intermediates was found in iPSC-derived-CMs from patients with very long-chain acyl-CoA dehydrogenase deficiency (VLCADD), who present life-threatening arrhythmias, leading to cardiac arrhythmias. This study proved that the use of agents such as etomoxir and resveratrol, resulted in reversion of these abnormalities and restoration of the correct phenotype, suggesting the possible use of these compounds in the therapy of VLCADD-CMs [336]. Moreover, as demonstrated by Loboda and Dulak, hiPSC generated from Duchenne muscular dystrophy (DMD) patients and differentiated into CMs showed an increase in arrhythmic events rate in comparison to isogenic control. Interestingly, stimulating this $\mathrm{CM}$ with propranolol abolished this effect in vivo, suggesting it as a potential clinical treatment for patients developing DMD-associated cardiomyopathy [337]. 
The use of iPSC-derived-CMs in modeling of heart disease can significantly accelerate the drug development process, but without diminishing the importance of downstream characterization and validation in animal models.

\section{Obtaining a Reproducible and Sufficient Number of hiPSC-Derived-CMs}

In cardiovascular research, it is not possible to obtain a sufficient number of all cell types because of the high level of invasive procedures required to obtain them. In addition, the low proliferative capacity of CMs limits the ability of researchers to maintain these cells in culture. In contrast, hiPSC technology has triggered a paradigm shift in drug discovery and clinical trials. Furthermore, hiPSCs circumvent many of the problems associated with animal and primary cell models and enable the mass production of large numbers of patient- and disease-specific CMs and other cardiac cell types [338,339]. The main advantage of hiPSC-derived-CMs models is that they can expand indefinitely and provide more physiologically and clinically relevant, reproducible human cell models for in vitro disease modeling and high-throughput drug screening with low cost and a limited number of animals for experiments [182,340,341]. To enable high throughput, a multilayer flask format with a surface area of up to $875 \mathrm{~cm}^{2}$ has been developed (Corning, Falcon) [342]. In addition, several automated systems, such as multi-channel liquid handling robots on the bench, have been used to maintain hiPSC in a 96-well format, which helps to minimize technical and biological variance [343,344], an important innovation has been the development of platforms to differentiate hPSCs into CMs at $80 \%$ purity in suspension culture [345]. Despite these capabilities, there are still some limitations. Conventional monolayer cultures provide limited surface area and require repeated subculturing to obtain large numbers of hiPSC-derived-CMs. In addition, the replacement of 3D culture models for drug discovery and therapy will require large-scale production of hiPSCsderived-CMs. Therefore, large-scale production of 3D CMs from iPSC can be achieved by various strategies, including suspension culture [346-348] or suspension using microcarrier substrates [349]. Further, to reduce the physical stress on cells caused by mechanical agitation or collisions with microcarriers, other researchers have developed bioreactor tanks and obtained 40 million ventricle-like CM in 100-mL bioreactors with purity up to 85\% [350]. Interestingly, Konagaya et al., developed a compact automated culture system for maintaining hiPSC undifferentiated state by the system for 60 days [351].

\section{Conclusions and Challenges}

Previous models for drug screening in humans have been based on immortalized tumor-derived cell lines and animal models, which are generally expensive, have low throughput, and differ in human cardiac physiology. While primary human CMs directly model the effects of a drug on humans, their availability and expansion capacity are limited and finite compared to in vitro derived cell lines. The limited access to human cardiac tissue biopsies and primary CMs has promoted the idea of using hiPSC-derivedCMs not only for drug discovery but also for disease modeling. In this context, the combination of hiPSC-derived-CMs with genome editing techniques such as CRISPR/Cas9 has become an indispensable tool of human cellular models to mimic the phenotype of human diseases in vitro and further advance our understanding of specific genetic cardiomyopathies and drug development in cardiovascular medicine. Despite the great advantages and high efficiency of obtaining CMs from iPSC, many challenges still need to be overcome to use hiPSC-derived-CMs for drug discovery. This is especially true for the structure, metabolism, signal transduction, and maturation of hiPSC-derived-CMs. This is particularly important for studying the phenomenon of QT elongation, which is often a side effect of the drugs tested. Recently, several studies have attempted to improve the maturation of hiPSC-derived-CMs in different ways, including the use of T3 hormone, metabolic maturation, 3D construction, mechanical stress, electrical stimulation, long-term cultivation, and co-culture with other cell types such as cardiac fibroblasts and endothelial cells. The advancement of 3D cardiac structures enabled the development of 
systems more accurately, the physiological phenotype and drug-induced responses, in comparison to their 2D counterparts. Further, the automated cell culture results in largescale production of hiPSC, which is useful to improve the reproducibility of cell cultures and reduce the time and effort of researchers. Nevertheless, there are still some limitations to be resolved. On the one hand, for $\mathrm{CM}$ transplantation, mature $\mathrm{CMs}$ cannot be transplanted into damaged myocardium, and neonatal cells can only survive to form new myocardium [352], so this may be disadvantageous for regenerative medicine applications. Therefore, the mature iPSC-derived-CMs may be not suitable for regenerative medicine. Second, it is the scalability of iPSC-derived-CMs production, which is inversely proportional to scalability, cost, and reproducibility. Therefore, a combination of ascorbic acid and growth factors can effectively improve the differentiation efficiency and maturity of iPSC-CMs [93]. However, the emerging iPSC technology cannot completely replace animal models but represents considerable advantages over classical in vitro models, by offering more clinically relevant tissue samples, using efficient, high-performance tools to test drugs efficiently, as well as drug development process, reducing time and cost-effects than those currently available.

Author Contributions: Personally contributed to the conception and writing of the manuscript, M.M.B.; review and editing the manuscript, P.C.S. All authors have read and agreed to the published version of the manuscript.

Funding: This research received no external funding.

Institutional Review Board Statement: Not applicable.

Informed Consent Statement: Not applicable.

Data Availability Statement: Not applicable.

Conflicts of Interest: The authors declare no conflict of interest.

\section{References}

1. Maron, B.J.; Towbin, J.A.; Thiene, G.; Antzelevitch, C.; Corrado, D.; Arnett, D.; Moss, A.J.; Seidman, C.E.; Young, J.B.; American Heart, A.; et al. Contemporary definitions and classification of the cardiomyopathies: An American Heart Association Scientific Statement from the Council on Clinical Cardiology, Heart Failure and Transplantation Committee; Quality of Care and Outcomes Research and Functional Genomics and Translational Biology Interdisciplinary Working Groups; and Council on Epidemiology and Prevention. Circulation 2006, 113, 1807-1816. [CrossRef] [PubMed]

2. Ziaeian, B.; Fonarow, G.C. Epidemiology and aetiology of heart failure. Nat. Rev. Cardiol. 2016, 13, 368-378. [CrossRef]

3. Brodehl, A.; Ebbinghaus, H.; Deutsch, M.A.; Gummert, J.; Gartner, A.; Ratnavadivel, S.; Milting, H. Human Induced Pluripotent Stem-Cell-Derived Cardiomyocytes as Models for Genetic Cardiomyopathies. Int. J. Mol. Sci. 2019, 20, 4381-4437. [CrossRef] [PubMed]

4. Minoche, A.E.; Horvat, C.; Johnson, R.; Gayevskiy, V.; Morton, S.U.; Drew, A.P.; Woo, K.; Statham, A.L.; Lundie, B.; Bagnall, R.D.; et al. Genome sequencing as a first-line genetic test in familial dilated cardiomyopathy. Genet. Med. 2019, 21, 650-662. [CrossRef]

5. Halapas, A.; Papalois, A.; Stauropoulou, A.; Philippou, A.; Pissimissis, N.; Chatzigeorgiou, A.; Kamper, E.; Koutsilieris, M. In vivo models for heart failure research. Vivo 2008, 22, 767-780.

6. Riehle, C.; Bauersachs, J. Small animal models of heart failure. Cardiovasc. Res. 2019, 115, 1838-1849. [CrossRef]

7. Houser, S.R.; Margulies, K.B.; Murphy, A.M.; Spinale, F.G.; Francis, G.S.; Prabhu, S.D.; Rockman, H.A.; Kass, D.A.; Molkentin, J.D.; Sussman, M.A.; et al. Animal Models of Heart Failure. Circ. Res. 2012, 111, 131-150. [CrossRef] [PubMed]

8. Jimenez-Tellez, N.; Greenway, S.C. Cellular models for human cardiomyopathy: What is the best option? World J. Cardiol. 2019, 11, 221-235. [CrossRef] [PubMed]

9. Bell, R.M.; Mocanu, M.M.; Yellon, D.M. Retrograde heart perfusion: The Langendorff technique of isolated heart perfusion. J. Mol. Cell Cardiol. 2011, 50, 940-950. [CrossRef]

10. Chlopcíková, S.; Psotová, J.; Miketová, P. Neonatal rat cardiomyocytes-a model for the study of morphological, biochemical and electrophysiological characteristics of the heart. Biomed. Pap. Palacky Univ. Olomouc 2001, 145, 49-55. [CrossRef]

11. Kimes, B.W.; Brandt, B.L. Properties of a clonal muscle cell line from rat heart. Exp. Cell Res. 1976, 98, 367-381. [CrossRef]

12. Steinhelper, M.E.; Lanson, N.A.; Dresdner, K.P.; Delcarpio, J.B.; Wit, A.L.; Claycomb, W.C.; Field, L.J. Proliferation Invivo and in Culture of Differentiated Adult Atrial Cardiomyocytes from Transgenic Mice. Am. J. Physiol. 1990, 259, H1826-H1834.

13. Delcarpio, J.B.; Lanson, N.A.; Field, L.J.; Claycomb, W.C. Morphological Characterization of Cardiomyocytes Isolated from a Transplantable Cardiac Tumor Derived from Transgenic Mouse Atria (at-1 Cells). Circ. Res. 1991, 69, 1591-1600. [CrossRef] [PubMed] 
14. Jaffredo, T.; Chestier, A.; Bachnou, N.; Dieterlenlievre, F. Mc29-Immortalized Clonal Avian Heart Cell-Lines Can Partially Differentiate Invitro. Exp. Cell Res. 1991, 192, 481-491. [CrossRef]

15. Claycomb, W.C.; Lanson, N.A.; Stallworth, B.S.; Egeland, D.B.; Delcarpio, J.B.; Bahinski, A.; Izzo, N.J. HL-1 cells: A cardiac muscle cell line that contracts and retains phenotypic characteristics of the adult cardiomyocyte. Proc. Natl. Acad. Sci. USA 1998, 95, 2979-2984. [CrossRef] [PubMed]

16. Davidson, M.M.; Nesti, C.; Palenzuela, L.; Walker, W.F.; Hernandez, E.; Protas, L.; Hirano, M.; Isaac, N.D. Novel cell lines derived from adult human ventricular cardiomyocytes. J. Mol. Cell. Cardiol. 2005, 39, 133-147. [CrossRef] [PubMed]

17. Merner, N.D.; Hodgkinson, K.A.; Haywood, A.F.M.; Connors, S.; French, V.M.; Drenckhahn, J.D.; Kupprion, C.; Ramadanova, K.; Thierfelder, L.; McKenna, W.; et al. Arrhythmogenic right ventricular cardiomyopathy type 5 is a fully penetrant, lethal arrhythmic disorder caused by a missense mutation in the TMEM43 gene. Am. J. Hum. Genet. 2008, 82, 809-821. [CrossRef] [PubMed]

18. Milting, H.; Klauke, B.; Christensen, A.H.; Musebeck, J.; Walhorn, V.; Grannemann, S.; Munnich, T.; Saric, T.; Rasmussen, T.B.; Jensen, H.K.; et al. The TMEM43 Newfoundland mutation p.S358L causing ARVC-5 was imported from Europe and increases the stiffness of the cell nucleus. Eur. Heart J. 2015, 36, 872-881. [CrossRef]

19. Stroud, M.J.; Fang, X.; Zhang, J.L.; Guimaraes-Camboa, N.; Veevers, J.; Dalton, N.D.; Gu, Y.; Bradford, W.H.; Peterson, K.L.; Evans, S.M.; et al. Luma is not essential for murine cardiac development and function. Cardiovasc. Res. 2018, 114, 378-388. [CrossRef] [PubMed]

20. Oh, J.G.; Kho, C.; Hajjar, R.J.; Ishikawa, K. Experimental models of cardiac physiology and pathology. Heart Fail. Rev. 2019, 24, 601-615. [CrossRef]

21. Takahashi, K.; Yamanaka, S. Induction of pluripotent stem cells from mouse embryonic and adult fibroblast cultures by defined factors. Cell 2006, 126, 663-676. [CrossRef] [PubMed]

22. Zhang, J.; Wilson, G.F.; Soerens, A.G.; Koonce, C.H.; Yu, J.; Palecek, S.P.; Thomson, J.A.; Kamp, T.J. Functional cardiomyocytes derived from human induced pluripotent stem cells. Circ. Res. 2009, 104, e30-e41. [CrossRef]

23. Thomson, J.A.; Itskovitz-Eldor, J.; Shapiro, S.S.; Waknitz, M.A.; Swiergiel, J.J.; Marshall, V.S.; Jones, J.M. Embryonic stem cell lines derived from human blastocysts. Science 1998, 282, 1145-1147. [CrossRef] [PubMed]

24. Medvedev, S.P.; Malakhova, A.A.; Grigor'eva, E.V.; Shevchenko, A.I.; Dementyeva, E.V.; Sobolev, I.A.; Lebedev, I.N.; Shilov, A.G.; Zhimulev, I.F.; Zakian, S.M. Derivation of induced pluripotent stem cells from fetal human skin fibroblasts. Acta Nat. 2010, 2, 102-106. [CrossRef]

25. Van Mil, A.; Balk, G.M.; Neef, K.; Buikema, J.W.; Asselbergs, F.W.; Wu, S.M.; Doevendans, P.A.; Sluijter, J.P.G. Modelling inherited cardiac disease using human induced pluripotent stem cell-derived cardiomyocytes: Progress, pitfalls, and potential. Cardiovasc. Res. 2018, 114, 1828-1842. [CrossRef] [PubMed]

26. Ebert, A.D.; Liang, P.; Wu, J.C. Induced pluripotent stem cells as a disease modeling and drug screening platform. J. Cardiovasc. Pharmacol. 2012, 60, 408-416. [CrossRef] [PubMed]

27. Kim, J.; Koo, B.-K.; Knoblich, J.A. Human organoids: Model systems for human biology and medicine. Nat. Rev. Mol. Cell Biol. 2020, 21, 571-584. [CrossRef]

28. Takahashi, K.; Tanabe, K.; Ohnuki, M.; Narita, M.; Ichisaka, T.; Tomoda, K.; Yamanaka, S. Induction of pluripotent stem cells from adult human fibroblasts by defined factors. Cell 2007, 131, 861-872. [CrossRef]

29. Nakagawa, M.; Koyanagi, M.; Tanabe, K.; Takahashi, K.; Ichisaka, T.; Aoi, T.; Okita, K.; Mochiduki, Y.; Takizawa, N.; Yamanaka, S. Generation of induced pluripotent stem cells without Myc from mouse and human fibroblasts. Nat. Biotechnol. 2008, 26, 101-106. [CrossRef]

30. Takahashi, K.; Yamanaka, S. A decade of transcription factor-mediated reprogramming to pluripotency. Nat. Rev. Mol. Cell Biol. 2016, 17, 183-193. [CrossRef] [PubMed]

31. Yu, J.; Vodyanik, M.A.; Smuga-Otto, K.; Antosiewicz-Bourget, J.; Frane, J.L.; Tian, S.; Nie, J.; Jonsdottir, G.A.; Ruotti, V.; Stewart, R.; et al. Induced pluripotent stem cell lines derived from human somatic cells. Science 2007, 318, 1917-1920. [CrossRef]

32. Wernig, M.; Lengner, C.J.; Hanna, J.; Lodato, M.A.; Steine, E.; Foreman, R.; Staerk, J.; Markoulaki, S.; Jaenisch, R. A drug-inducible transgenic system for direct reprogramming of multiple somatic cell types. Nat. Biotechnol. 2008, 26, 916-924. [CrossRef] [PubMed]

33. Nandan, M.O.; Yang, V.W. The role of Krüppel-like factors in the reprogramming of somatic cells to induced pluripotent stem cells. Histol. Histopathol. 2009, 24, 1343-1355. [CrossRef]

34. Plath, K.; Lowry, W.E. Progress in understanding reprogramming to the induced pluripotent state. Nat. Rev. Genet. 2011, 12, 253-265. [CrossRef]

35. Jiang, J.; Chan, Y.S.; Loh, Y.H.; Cai, J.; Tong, G.Q.; Lim, C.A.; Robson, P.; Zhong, S.; Ng, H.H. A core Klf circuitry regulates self-renewal of embryonic stem cells. Nat. Cell Biol. 2008, 10, 353-360. [CrossRef] [PubMed]

36. Fu, K.; Chronis, C.; Soufi, A.; Bonora, G.; Edwards, M.; Smale, S.T.; Zaret, K.S.; Plath, K.; Pellegrini, M. Comparison of reprogramming factor targets reveals both species-specific and conserved mechanisms in early iPSC reprogramming. BMC Genom. 2018, 19, 956. [CrossRef] [PubMed]

37. Feng, B.; Ng, J.H.; Heng, J.C.; Ng, H.H. Molecules that promote or enhance reprogramming of somatic cells to induced pluripotent stem cells. Cell Stem Cell 2009, 4, 301-312. [CrossRef] 
38. Seki, T.; Yuasa, S.; Oda, M.; Egashira, T.; Yae, K.; Kusumoto, D.; Nakata, H.; Tohyama, S.; Hashimoto, H.; Kodaira, M.; et al. Generation of induced pluripotent stem cells from human terminally differentiated circulating T cells. Cell Stem Cell 2010, 7, 11-14. [CrossRef]

39. Staerk, J.; Dawlaty, M.M.; Gao, Q.; Maetzel, D.; Hanna, J.; Sommer, C.A.; Mostoslavsky, G.; Jaenisch, R. Reprogramming of human peripheral blood cells to induced pluripotent stem cells. Cell Stem Cell 2010, 7, 20-24. [CrossRef] [PubMed]

40. Zhou, T.; Benda, C.; Duzinger, S.; Huang, Y.; Li, X.; Li, Y.; Guo, X.; Cao, G.; Chen, S.; Hao, L.; et al. Generation of induced pluripotent stem cells from urine. J. Am. Soc. Nephrol. 2011, 22, 1221-1228. [CrossRef]

41. Churko, J.M.; Burridge, P.W.; Wu, J.C. Generation of human iPSCs from human peripheral blood mononuclear cells using non-integrative Sendai virus in chemically defined conditions. Methods Mol. Biol. 2013, 1036, 81-88. [CrossRef] [PubMed]

42. Dadheech, N.; James Shapiro, A.M. Human Induced Pluripotent Stem Cells in the Curative Treatment of Diabetes and Potential Impediments Ahead. Adv. Exp. Med. Biol. 2019, 1144, 25-35. [CrossRef]

43. Park, I.H.; Arora, N.; Huo, H.; Maherali, N.; Ahfeldt, T.; Shimamura, A.; Lensch, M.W.; Cowan, C.; Hochedlinger, K.; Daley, G.Q. Disease-specific induced pluripotent stem cells. Cell 2008, 134, 877-886. [CrossRef] [PubMed]

44. Petit, I.; Kesner, N.S.; Karry, R.; Robicsek, O.; Aberdam, E.; Müller, F.J.; Aberdam, D.; Ben-Shachar, D. Induced pluripotent stem cells from hair follicles as a cellular model for neurodevelopmental disorders. Stem Cell Res. 2012, 8, 134-140. [CrossRef] [PubMed]

45. Chang, W.Y.; Lavoie, J.R.; Kwon, S.Y.; Chen, Z.; Manias, J.L.; Behbahani, J.; Ling, V.; Kandel, R.A.; Stewart, D.J.; Stanford, W.L. Feeder-independent derivation of induced-pluripotent stem cells from peripheral blood endothelial progenitor cells. Stem Cell Res. 2013, 10, 195-202. [CrossRef] [PubMed]

46. Aoi, T.; Yae, K.; Nakagawa, M.; Ichisaka, T.; Okita, K.; Takahashi, K.; Chiba, T.; Yamanaka, S. Generation of pluripotent stem cells from adult mouse liver and stomach cells. Science 2008, 321, 699-702. [CrossRef]

47. Zhou, Y.Y.; Zeng, F. Integration-free methods for generating induced pluripotent stem cells. Genom. Proteom. Bioinform. 2013, 11, 284-287. [CrossRef]

48. Fusaki, N.; Ban, H.; Nishiyama, A.; Saeki, K.; Hasegawa, M. Efficient induction of transgene-free human pluripotent stem cells using a vector based on Sendai virus, an RNA virus that does not integrate into the host genome. Proc. Jpn. Acad. Ser. B Phys. Biol Sci. 2009, 85, 348-362. [CrossRef]

49. Zhou, H.; Wu, S.; Joo, J.Y.; Zhu, S.; Han, D.W.; Lin, T.; Trauger, S.; Bien, G.; Yao, S.; Zhu, Y.; et al. Generation of induced pluripotent stem cells using recombinant proteins. Cell Stem Cell 2009, 4, 381-384. [CrossRef]

50. Deng, X.Y.; Wang, H.; Wang, T.; Fang, X.T.; Zou, L.L.; Li, Z.Y.; Liu, C.B. Non-viral methods for generating integration-free, induced pluripotent stem cells. Curr. Stem Cell Res. Ther. 2015, 10, 153-158. [CrossRef]

51. Kime, C.; Rand, T.A.; Ivey, K.N.; Srivastava, D.; Yamanaka, S.; Tomoda, K. Practical Integration-Free Episomal Methods for Generating Human Induced Pluripotent Stem Cells. Curr. Protoc. Hum. Genet. 2015, 87, 21.22.1-21.22.21. [CrossRef] [PubMed]

52. Schlaeger, T.M.; Daheron, L.; Brickler, T.R.; Entwisle, S.; Chan, K.; Cianci, A.; DeVine, A.; Ettenger, A.; Fitzgerald, K.; Godfrey, M.; et al. A comparison of non-integrating reprogramming methods. Nat. Biotechnol. 2015, 33, 58-63. [CrossRef] [PubMed]

53. Ban, H.; Nishishita, N.; Fusaki, N.; Tabata, T.; Saeki, K.; Shikamura, M.; Takada, N.; Inoue, M.; Hasegawa, M.; Kawamata, S.; et al. Efficient generation of transgene-free human induced pluripotent stem cells (iPSCs) by temperature-sensitive Sendai virus vectors. Proc. Natl. Acad. Sci. USA 2011, 108, 14234-14239. [CrossRef] [PubMed]

54. Ono, M.; Hamada, Y.; Horiuchi, Y.; Matsuo-Takasaki, M.; Imoto, Y.; Satomi, K.; Arinami, T.; Hasegawa, M.; Fujioka, T.; Nakamura, Y.; et al. Generation of induced pluripotent stem cells from human nasal epithelial cells using a Sendai virus vector. PLoS ONE 2012, 7, e42855. [CrossRef]

55. Seki, T.; Yuasa, S.; Fukuda, K. Generation of induced pluripotent stem cells from a small amount of human peripheral blood using a combination of activated T cells and Sendai virus. Nat. Protoc. 2012, 7, 718-728. [CrossRef] [PubMed]

56. Macarthur, C.C.; Fontes, A.; Ravinder, N.; Kuninger, D.; Kaur, J.; Bailey, M.; Taliana, A.; Vemuri, M.C.; Lieu, P.T. Generation of human-induced pluripotent stem cells by a nonintegrating RNA Sendai virus vector in feeder-free or xeno-free conditions. Stem Cells Int. 2012, 2012, 564612. [CrossRef]

57. Okita, K.; Nakagawa, M.; Hyenjong, H.; Ichisaka, T.; Yamanaka, S. Generation of mouse induced pluripotent stem cells without viral vectors. Science 2008, 322, 949-953. [CrossRef] [PubMed]

58. Okita, K.; Hong, H.; Takahashi, K.; Yamanaka, S. Generation of mouse-induced pluripotent stem cells with plasmid vectors. Nat. Protoc. 2010, 5, 418-428. [CrossRef] [PubMed]

59. Okita, K.; Matsumura, Y.; Sato, Y.; Okada, A.; Morizane, A.; Okamoto, S.; Hong, H.; Nakagawa, M.; Tanabe, K.; Tezuka, K.; et al. A more efficient method to generate integration-free human iPS cells. Nat. Methods 2011, 8, 409-412. [CrossRef] [PubMed]

60. Yu, J.; Hu, K.; Smuga-Otto, K.; Tian, S.; Stewart, R.; Slukvin, I., I; Thomson, J.A. Human induced pluripotent stem cells free of vector and transgene sequences. Science 2009, 324, 797-801. [CrossRef] [PubMed]

61. Gonzalez, F.; Barragan Monasterio, M.; Tiscornia, G.; Montserrat Pulido, N.; Vassena, R.; Batlle Morera, L.; Rodriguez Piza, I.; Izpisua Belmonte, J.C. Generation of mouse-induced pluripotent stem cells by transient expression of a single nonviral polycistronic vector. Proc. Natl. Acad. Sci. USA 2009, 106, 8918-8922. [CrossRef] [PubMed]

62. Meraviglia, V.; Zanon, A.; Lavdas, A.A.; Schwienbacher, C.; Silipigni, R.; Di Segni, M.; Chen, H.S.; Pramstaller, P.P.; Hicks, A.A.; Rossini, A. Generation of Induced Pluripotent Stem Cells from Frozen Buffy Coats using Non-integrating Episomal Plasmids. J. Vis. Exp. 2015, 5, 52885-52909. [CrossRef] 
63. Narsinh, K.H.; Jia, F.; Robbins, R.C.; Kay, M.A.; Longaker, M.T.; Wu, J.C. Generation of adult human induced pluripotent stem cells using nonviral minicircle DNA vectors. Nat. Protoc. 2011, 6, 78-88. [CrossRef] [PubMed]

64. Jia, F.; Wilson, K.D.; Sun, N.; Gupta, D.M.; Huang, M.; Li, Z.; Panetta, N.J.; Chen, Z.Y.; Robbins, R.C.; Kay, M.A.; et al. A nonviral minicircle vector for deriving human iPS cells. Nat. Methods 2010, 7, 197-199. [CrossRef]

65. Kaji, K.; Norrby, K.; Paca, A.; Mileikovsky, M.; Mohseni, P.; Woltjen, K. Virus-free induction of pluripotency and subsequent excision of reprogramming factors. Nature 2009, 458, 771-775. [CrossRef]

66. Warren, L.; Manos, P.D.; Ahfeldt, T.; Loh, Y.H.; Li, H.; Lau, F.; Ebina, W.; Mandal, P.K.; Smith, Z.D.; Meissner, A.; et al. Highly efficient reprogramming to pluripotency and directed differentiation of human cells with synthetic modified mRNA. Cell Stem Cell 2010, 7, 618-630. [CrossRef] [PubMed]

67. Warren, L.; Ni, Y.; Wang, J.; Guo, X. Feeder-free derivation of human induced pluripotent stem cells with messenger RNA. Sci Rep. 2012, 2, 657. [CrossRef] [PubMed]

68. Card, D.A.; Hebbar, P.B.; Li, L.; Trotter, K.W.; Komatsu, Y.; Mishina, Y.; Archer, T.K. Oct4/Sox2-regulated miR-302 targets cyclin D1 in human embryonic stem cells. Mol. Cell Biol. 2008, 28, 6426-6438. [CrossRef] [PubMed]

69. Anokye-Danso, F.; Trivedi, C.M.; Juhr, D.; Gupta, M.; Cui, Z.; Tian, Y.; Zhang, Y.; Yang, W.; Gruber, P.J.; Epstein, J.A.; et al. Highly efficient miRNA-mediated reprogramming of mouse and human somatic cells to pluripotency. Cell Stem Cell 2011, 8, 376-388. [CrossRef]

70. Han, M.J.; Kim, H.R.; O’Reilly, C.; Kim, C.H. Purification of functional reprogramming factors in mammalian cell using FLAG -Tag. Biochem. Biophys. Res. Commun. 2017, 492, 154-160. [CrossRef]

71. Savić, N.; Schwank, G. Advances in therapeutic CRISPR/Cas9 genome editing. Transl. Res. 2016, 168, 15-21. [CrossRef] [PubMed]

72. Weltner, J.; Balboa, D.; Katayama, S.; Bespalov, M.; Krjutškov, K.; Jouhilahti, E.M.; Trokovic, R.; Kere, J.; Otonkoski, T. Human pluripotent reprogramming with CRISPR activators. Nat. Commun. 2018, 9, 2643. [CrossRef] [PubMed]

73. Hsu, P.D.; Lander, E.S.; Zhang, F. Development and applications of CRISPR-Cas9 for genome engineering. Cell 2014, 157, 1262-1278. [CrossRef] [PubMed]

74. Dominguez, A.A.; Lim, W.A.; Qi, L.S. Beyond editing: Repurposing CRISPR-Cas9 for precision genome regulation and interrogation. Nat. Rev. Mol. Cell Biol. 2016, 17, 5-15. [CrossRef] [PubMed]

75. Mahas, A.; Neal Stewart, C., Jr.; Mahfouz, M.M. Harnessing CRISPR/Cas systems for programmable transcriptional and post-transcriptional regulation. Biotechnol. Adv. 2018, 36, 295-310. [CrossRef] [PubMed]

76. Müller-Werdan, U.; Klein, D.; Zander, M.; Werdan, K.; Hammer, C. Beating neonatal rat cardiomyocytes as a model to study the role of xenoreactive natural antibodies in xenotransplantation. Transplantation 1994, 58, 1403-1409.

77. Louch, W.E.; Sheehan, K.A.; Wolska, B.M. Methods in cardiomyocyte isolation, culture, and gene transfer. J. Mol. Cell Cardiol. 2011, 51, 288-298. [CrossRef] [PubMed]

78. Dias, P.; Desplantez, T.; El-Harasis, M.A.; Chowdhury, R.A.; Ullrich, N.D.; Cabestrero de Diego, A.; Peters, N.S.; Severs, N.J.; MacLeod, K.T.; Dupont, E. Characterisation of connexin expression and electrophysiological properties in stable clones of the HL-1 myocyte cell line. PLoS ONE 2014, 9, e90266. [CrossRef] [PubMed]

79. Zwi, L.; Caspi, O.; Arbel, G.; Huber, I.; Gepstein, A.; Park, I.H.; Gepstein, L. Cardiomyocyte differentiation of human induced pluripotent stem cells. Circulation 2009, 120, 1513-1523. [CrossRef]

80. Burridge, P.W.; Thompson, S.; Millrod, M.A.; Weinberg, S.; Yuan, X.; Peters, A.; Mahairaki, V.; Koliatsos, V.E.; Tung, L.; Zambidis, E.T. A universal system for highly efficient cardiac differentiation of human induced pluripotent stem cells that eliminates interline variability. PLOS ONE 2011, 6, e18293. [CrossRef]

81. Hatani, T.; Miki, K.; Yoshida, Y. Induction of Human Induced Pluripotent Stem Cells to Cardiomyocytes Using Embryoid Bodies. Methods Mol. Biol. 2018, 1816, 79-92. [CrossRef] [PubMed]

82. Lian, X.; Zhang, J.; Azarin, S.M.; Zhu, K.; Hazeltine, L.B.; Bao, X.; Hsiao, C.; Kamp, T.J.; Palecek, S.P. Directed cardiomyocyte differentiation from human pluripotent stem cells by modulating Wnt/ $\beta$-catenin signaling under fully defined conditions. Nat. Protoc. 2013, 8, 162-175. [CrossRef] [PubMed]

83. Lian, X.; Hsiao, C.; Wilson, G.; Zhu, K.; Hazeltine, L.B.; Azarin, S.M.; Raval, K.K.; Zhang, J.; Kamp, T.J.; Palecek, S.P. Robust cardiomyocyte differentiation from human pluripotent stem cells via temporal modulation of canonical Wnt signaling. Proc. Natl. Acad. Sci. USA 2012, 109, E1848-E1857. [CrossRef]

84. Burridge, P.W.; Matsa, E.; Shukla, P.; Lin, Z.C.; Churko, J.M.; Ebert, A.D.; Lan, F.; Diecke, S.; Huber, B.; Mordwinkin, N.M.; et al. Chemically defined generation of human cardiomyocytes. Nat. Methods 2014, 11, 855-860. [CrossRef] [PubMed]

85. Kim, M.S.; Horst, A.; Blinka, S.; Stamm, K.; Mahnke, D.; Schuman, J.; Gundry, R.; Tomita-Mitchell, A.; Lough, J. Activin-A and Bmp4 levels modulate cell type specification during CHIR-induced cardiomyogenesis. PLoS ONE 2015, 10, e0118670. [CrossRef]

86. Fonoudi, H.; Ansari, H.; Abbasalizadeh, S.; Larijani, M.R.; Kiani, S.; Hashemizadeh, S.; Zarchi, A.S.; Bosman, A.; Blue, G.M.; Pahlavan, S.; et al. A Universal and Robust Integrated Platform for the Scalable Production of Human Cardiomyocytes From Pluripotent Stem Cells. Stem Cells Transl. Med. 2015, 4, 1482-1494. [CrossRef]

87. Lee, J.H.; Protze, S.I.; Laksman, Z.; Backx, P.H.; Keller, G.M. Human Pluripotent Stem Cell-Derived Atrial and Ventricular Cardiomyocytes Develop from Distinct Mesoderm Populations. Cell Stem Cell 2017, 21, 179-194.e174. [CrossRef]

88. Argenziano, M.; Lambers, E.; Hong, L.; Sridhar, A.; Zhang, M.; Chalazan, B.; Menon, A.; Savio-Galimberti, E.; Wu, J.C.; Rehman, J.; et al. Electrophysiologic Characterization of Calcium Handling in Human Induced Pluripotent Stem Cell-Derived Atrial Cardiomyocytes. Stem Cell Rep. 2018, 10, 1867-1878. [CrossRef] [PubMed] 
89. Kleinsorge, M.; Cyganek, L. Subtype-Directed Differentiation of Human iPSCs into Atrial and Ventricular Cardiomyocytes. STAR Protoc. 2020, 1, 100026. [CrossRef] [PubMed]

90. Protze, S.I.; Liu, J.; Nussinovitch, U.; Ohana, L.; Backx, P.H.; Gepstein, L.; Keller, G.M. Sinoatrial node cardiomyocytes derived from human pluripotent cells function as a biological pacemaker. Nat. Biotechnol. 2017, 35, 56-68. [CrossRef] [PubMed]

91. Liu, F.; Fang, Y.; Hou, X.; Yan, Y.; Xiao, H.; Zuo, D.; Wen, J.; Wang, L.; Zhou, Z.; Dang, X.; et al. Enrichment differentiation of human induced pluripotent stem cells into sinoatrial node-like cells by combined modulation of BMP, FGF, and RA signaling pathways. Stem Cell Res. Ther. 2020, 11, 284. [CrossRef] [PubMed]

92. Zhu, W.Z.; Xie, Y.; Moyes, K.W.; Gold, J.D.; Askari, B.; Laflamme, M.A. Neuregulin/ErbB signaling regulates cardiac subtype specification in differentiating human embryonic stem cells. Circ. Res. 2010, 107, 776-786. [CrossRef] [PubMed]

93. Yassa, M.E.; Mansour, I.A.; Sewelam, N.I.; Hamza, H.; Gaafar, T. The impact of growth factors on human induced pluripotent stem cells differentiation into cardiomyocytes. Life Sci. 2018, 196, 38-47. [CrossRef] [PubMed]

94. Zhao, Y.; Rafatian, N.; Wang, E.Y.; Wu, Q.; Lai, B.F.L.; Lu, R.X.; Savoji, H.; Radisic, M. Towards chamber specific heart-on-a-chip for drug testing applications. Adv. Drug Deliv. Rev. 2020, 165-166, 60-76. [CrossRef] [PubMed]

95. Navarrete, E.G.; Liang, P.; Lan, F.; Sanchez-Freire, V.; Simmons, C.; Gong, T.; Sharma, A.; Burridge, P.W.; Patlolla, B.; Lee, A.S.; et al. Screening drug-induced arrhythmia [corrected] using human induced pluripotent stem cell-derived cardiomyocytes and low-impedance microelectrode arrays. Circulation 2013, 128, S3-S13. [CrossRef] [PubMed]

96. Biendarra-Tiegs, S.M.; Li, X.; Ye, D.; Brandt, E.B.; Ackerman, M.J.; Nelson, T.J. Single-Cell RNA-Sequencing and Optical Electrophysiology of Human Induced Pluripotent Stem Cell-Derived Cardiomyocytes Reveal Discordance Between Cardiac Subtype-Associated Gene Expression Patterns and Electrophysiological Phenotypes. Stem Cells Dev. 2019, 28, 659-673. [CrossRef]

97. Cyganek, L.; Tiburcy, M.; Sekeres, K.; Gerstenberg, K.; Bohnenberger, H.; Lenz, C.; Henze, S.; Stauske, M.; Salinas, G.; Zimmermann, W.H.; et al. Deep phenotyping of human induced pluripotent stem cell-derived atrial and ventricular cardiomyocytes. JCI Insight 2018, 3, 99941-99959. [CrossRef]

98. Nafissi, N.A.; DeBenedittis, P.; Thomas, M.C.; Karra, R. Differentiation of Human Induced Pluripotent Stem Cells into EpicardialLike Cells. Methods Mol. Biol. 2021, 2158, 141-153. [CrossRef] [PubMed]

99. Lalit, P.A.; Salick, M.R.; Nelson, D.O.; Squirrell, J.M.; Shafer, C.M.; Patel, N.G.; Saeed, I.; Schmuck, E.G.; Markandeya, Y.S.; Wong, R.; et al. Lineage Reprogramming of Fibroblasts into Proliferative Induced Cardiac Progenitor Cells by Defined Factors. Cell Stem Cell 2016, 18, 354-367. [CrossRef]

100. Chen, W.; Bian, W.; Zhou, Y.; Zhang, J. Cardiac Fibroblasts and Myocardial Regeneration. Front. Bioeng. Biotechnol. 2021, 9 , 599928. [CrossRef]

101. Zhang, J.; Tao, R.; Campbell, K.F.; Carvalho, J.L.; Ruiz, E.C.; Kim, G.C.; Schmuck, E.G.; Raval, A.N.; da Rocha, A.M.; Herron, T.J.; et al. Functional cardiac fibroblasts derived from human pluripotent stem cells via second heart field progenitors. Nat. Commun. 2019, 10, 2238. [CrossRef]

102. Nachlas, A.L.Y.; Li, S.; Jha, R.; Singh, M.; Xu, C.; Davis, M.E. Human iPSC-derived mesenchymal stem cells encapsulated in PEGDA hydrogels mature into valve interstitial-like cells. Acta Biomater. 2018, 71, 235-246. [CrossRef]

103. Dash, B.C.; Jiang, Z.; Suh, C.; Qyang, Y. Induced pluripotent stem cell-derived vascular smooth muscle cells: Methods and application. Biochem. J. 2015, 465, 185-194. [CrossRef] [PubMed]

104. Shen, M.; Quertermous, T.; Fischbein, M.P.; Wu, J.C. Generation of Vascular Smooth Muscle Cells From Induced Pluripotent Stem Cells: Methods, Applications, and Considerations. Circ. Res. 2021, 128, 670-686. [CrossRef] [PubMed]

105. Patsch, C.; Challet-Meylan, L.; Thoma, E.C.; Urich, E.; Heckel, T.; O’Sullivan, J.F.; Grainger, S.J.; Kapp, F.G.; Sun, L.; Christensen, K.; et al. Generation of vascular endothelial and smooth muscle cells from human pluripotent stem cells. Nat. Cell Biol. 2015, 17, 994-1003. [CrossRef] [PubMed]

106. Dubois, N.C.; Craft, A.M.; Sharma, P.; Elliott, D.A.; Stanley, E.G.; Elefanty, A.G.; Gramolini, A.; Keller, G. SIRPA is a specific cell-surface marker for isolating cardiomyocytes derived from human pluripotent stem cells. Nat. Biotechnol. 2011, 29, 1011-1018. [CrossRef] [PubMed]

107. Uosaki, H.; Fukushima, H.; Takeuchi, A.; Matsuoka, S.; Nakatsuji, N.; Yamanaka, S.; Yamashita, J.K. Efficient and scalable purification of cardiomyocytes from human embryonic and induced pluripotent stem cells by VCAM1 surface expression. PLoS ONE 2011, 6, e23657. [CrossRef] [PubMed]

108. Kita-Matsuo, H.; Barcova, M.; Prigozhina, N.; Salomonis, N.; Wei, K.; Jacot, J.G.; Nelson, B.; Spiering, S.; Haverslag, R.; Kim, C.; et al. Lentiviral vectors and protocols for creation of stable hESC lines for fluorescent tracking and drug resistance selection of cardiomyocytes. PLoS ONE 2009, 4, e5046. [CrossRef] [PubMed]

109. Ma, J.; Guo, L.; Fiene, S.J.; Anson, B.D.; Thomson, J.A.; Kamp, T.J.; Kolaja, K.L.; Swanson, B.J.; January, C.T. High purity human-induced pluripotent stem cell-derived cardiomyocytes: Electrophysiological properties of action potentials and ionic currents. Am. J. Physiol. Heart Circ. Physiol. 2011, 301, H2006-2017. [CrossRef]

110. Tohyama, S.; Hattori, F.; Sano, M.; Hishiki, T.; Nagahata, Y.; Matsuura, T.; Hashimoto, H.; Suzuki, T.; Yamashita, H.; Satoh, Y.; et al. Distinct metabolic flow enables large-scale purification of mouse and human pluripotent stem cell-derived cardiomyocytes. Cell Stem Cell 2013, 12, 127-137. [CrossRef]

111. Ahmed, R.E.; Anzai, T.; Chanthra, N.; Uosaki, H. A Brief Review of Current Maturation Methods for Human Induced Pluripotent Stem Cells-Derived Cardiomyocytes. Front. Cell Dev. Biol. 2020, 8, 178. [CrossRef] 
112. Bedada, F.B.; Wheelwright, M.; Metzger, J.M. Maturation status of sarcomere structure and function in human iPSC-derived cardiac myocytes. Biochim. Biophys. Acta 2016, 1863, 1829-1838. [CrossRef]

113. Bekhite, M.M.; Gonzalez Delgado, A.; Menz, F.; Kretzschmar, T.; Wu, J.M.F.; Bekfani, T.; Nietzsche, S.; Wartenberg, M.; Westermann, M.; Greber, B.; et al. Longitudinal metabolic profiling of cardiomyocytes derived from human-induced pluripotent stem cells. Basic Res. Cardiol. 2020, 115, 37. [CrossRef] [PubMed]

114. Zuppinger, C.; Gibbons, G.; Dutta-Passecker, P.; Segiser, A.; Most, H.; Suter, T.M. Characterization of cytoskeleton features and maturation status of cultured human iPSC-derived cardiomyocytes. Eur. J. Histochem. 2017, 61, 2763. [CrossRef]

115. Guo, Y.; Pu, W.T. Cardiomyocyte Maturation: New Phase in Development. Circ. Res. 2020, 126, 1086-1106. [CrossRef]

116. Kim, H.D.; Kim, D.J.; Lee, I.J.; Rah, B.J.; Sawa, Y.; Schaper, J. Human fetal heart development after mid-term: Morphometry and ultrastructural study. J. Mol. Cell Cardiol. 1992, 24, 949-965. [CrossRef]

117. Mollova, M.; Bersell, K.; Walsh, S.; Savla, J.; Das, L.T.; Park, S.Y.; Silberstein, L.E.; Dos Remedios, C.G.; Graham, D.; Colan, S.; et al. Cardiomyocyte proliferation contributes to heart growth in young humans. Proc. Natl. Acad. Sci. USA 2013, 110, 1446-1451. [CrossRef] [PubMed]

118. Peters, N.S.; Severs, N.J.; Rothery, S.M.; Lincoln, C.; Yacoub, M.H.; Green, C.R. Spatiotemporal relation between gap junctions and fascia adherens junctions during postnatal development of human ventricular myocardium. Circulation 1994, 90, 713-725. [CrossRef] [PubMed]

119. Skoglund, G.; Lainé, J.; Darabi, R.; Fournier, E.; Perlingeiro, R.; Tabti, N. Physiological and ultrastructural features of human induced pluripotent and embryonic stem cell-derived skeletal myocytes in vitro. Proc. Natl. Acad. Sci. USA 2014, 111, 8275-8280. [CrossRef] [PubMed]

120. Van der Velden, J.; Klein, L.J.; van der Bijl, M.; Huybregts, M.A.; Stooker, W.; Witkop, J.; Eijsman, L.; Visser, C.A.; Visser, F.C.; Stienen, G.J. Force production in mechanically isolated cardiac myocytes from human ventricular muscle tissue. Cardiovasc. Res. 1998, 38, 414-423. [CrossRef]

121. Lundy, S.D.; Zhu, W.Z.; Regnier, M.; Laflamme, M.A. Structural and functional maturation of cardiomyocytes derived from human pluripotent stem cells. Stem Cells Dev. 2013, 22, 1991-2002. [CrossRef]

122. Mills, R.J.; Titmarsh, D.M.; Koenig, X.; Parker, B.L.; Ryall, J.G.; Quaife-Ryan, G.A.; Voges, H.K.; Hodson, M.P.; Ferguson, C.; Drowley, L.; et al. Functional screening in human cardiac organoids reveals a metabolic mechanism for cardiomyocyte cell cycle arrest. Proc. Natl. Acad. Sci. USA 2017, 114, E8372-E8381. [CrossRef]

123. Yang, X.; Pabon, L.; Murry, C.E. Engineering adolescence: Maturation of human pluripotent stem cell-derived cardiomyocytes. Circ. Res. 2014, 114, 511-523. [CrossRef]

124. Jansen, J.A.; van Veen, T.A.B.; de Bakker, J.M.T.; van Rijen, H.V.M. Cardiac connexins and impulse propagation. J. Mol. Cell. Cardiol. 2010, 48, 76-82. [CrossRef] [PubMed]

125. Hunkeler, N.M.; Kullman, J.; Murphy, A.M. Troponin I isoform expression in human heart. Circ. Res. 1991, 69, 1409-1414. [CrossRef] [PubMed]

126. Saggin, L.; Gorza, L.; Ausoni, S.; Schiaffino, S. Troponin I switching in the developing heart. J. Biol. Chem. 1989, 264, 16299-16302. [CrossRef]

127. Mahdavi, V.; Lompre, A.M.; Chambers, A.P.; Nadal-Ginard, B. Cardiac myosin heavy chain isozymic transitions during development and under pathological conditions are regulated at the level of mRNA availability. Eur. Heart J. 1984, 5 (Suppl. F), 181-191. [CrossRef] [PubMed]

128. Wu, H.; Lee, J.; Vincent, L.G.; Wang, Q.; Gu, M.; Lan, F.; Churko, J.M.; Sallam, K.I.; Matsa, E.; Sharma, A.; et al. Epigenetic Regulation of Phosphodiesterases 2A and 3A Underlies Compromised $\beta$-Adrenergic Signaling in an iPSC Model of Dilated Cardiomyopathy. Cell Stem Cell 2015, 17, 89-100. [CrossRef] [PubMed]

129. Brodde, O.E. Beta 1- and beta 2-adrenoceptors in the human heart: Properties, function, and alterations in chronic heart failure. Pharm. Rev. 1991, 43, 203-242. [PubMed]

130. Engelhardt, S.; Böhm, M.; Erdmann, E.; Lohse, M.J. Analysis of beta-adrenergic receptor mRNA levels in human ventricular biopsy specimens by quantitative polymerase chain reactions: Progressive reduction of beta 1-adrenergic receptor mRNA in heart failure. J. Am. Coll Cardiol. 1996, 27, 146-154. [CrossRef]

131. Drouin, E.; Charpentier, F.; Gauthier, C.; Laurent, K.; Le Marec, H. Electrophysiologic characteristics of cells spanning the left ventricular wall of human heart: Evidence for presence of M cells. J. Am. Coll Cardiol. 1995, 26, 185-192. [CrossRef]

132. Goversen, B.; van der Heyden, M.A.G.; van Veen, T.A.B.; de Boer, T.P. The immature electrophysiological phenotype of iPSC-CMs still hampers in vitro drug screening: Special focus on I(K1). Pharm. Ther. 2018, 183, 127-136. [CrossRef] [PubMed]

133. Bers, D.M. Cardiac excitation-contraction coupling. Nature 2002, 415, 198-205. [CrossRef] [PubMed]

134. Lee, Y.-K.; Ng, K.-M.; Lai, W.-H.; Chan, Y.-C.; Lau, Y.-M.; Lian, Q.; Tse, H.-F.; Siu, C.-W. Calcium Homeostasis in Human Induced Pluripotent Stem Cell-Derived Cardiomyocytes. Stem Cell Rev. Rep. 2011, 7, 976-986. [CrossRef]

135. Koivumäki, J.T.; Naumenko, N.; Tuomainen, T.; Takalo, J.; Oksanen, M.; Puttonen, K.A.; Lehtonen, Š.; Kuusisto, J.; Laakso, M.; Koistinaho, J.; et al. Structural Immaturity of Human iPSC-Derived Cardiomyocytes: In Silico Investigation of Effects on Function and Disease Modeling. Front. Physiol. 2018, 9, 1-17. [CrossRef] [PubMed]

136. Itzhaki, I.; Rapoport, S.; Huber, I.; Mizrahi, I.; Zwi-Dantsis, L.; Arbel, G.; Schiller, J.; Gepstein, L. Calcium handling in human induced pluripotent stem cell derived cardiomyocytes. PLoS ONE 2011, 6, e18037. [CrossRef] 
137. Li, S.; Chen, G.; Li, R.A. Calcium signalling of human pluripotent stem cell-derived cardiomyocytes. J. Physiol. 2013, 591, 5279-5290. [CrossRef] [PubMed]

138. Kane, C.; Couch, L.; Terracciano, C.M.N. Excitation-contraction coupling of human induced pluripotent stem cell-derived cardiomyocytes. Front. Cell Dev. Biol. 2015, 3, 59. [CrossRef] [PubMed]

139. Machiraju, P.; Greenway, S.C. Current methods for the maturation of induced pluripotent stem cell-derived cardiomyocytes. World J. Stem Cells 2019, 11, 33-43. [CrossRef] [PubMed]

140. Goldberg, I.J.; Trent, C.M.; Schulze, P.C. Lipid metabolism and toxicity in the heart. Cell Metab. 2012, 15, 805-812. [CrossRef]

141. Stanley, W.C.; Recchia, F.A.; Lopaschuk, G.D. Myocardial substrate metabolism in the normal and failing heart. Physiol. Rev. 2005, 85, 1093-1129. [CrossRef] [PubMed]

142. Larsen, T.S.; Aasum, E. Metabolic (in)flexibility of the diabetic heart. Cardiovasc Drugs Ther. 2008, 22, 91-95. [CrossRef] [PubMed]

143. Batten, B.E.; Albertini, D.F.; Ducibella, T. Patterns of organelle distribution in mouse embryos during preimplantation development. Am. J. Anat. 1987, 178, 204-213. [CrossRef] [PubMed]

144. Wilding, M.; Dale, B.; Marino, M.; di Matteo, L.; Alviggi, C.; Pisaturo, M.L.; Lombardi, L.; De Placido, G. Mitochondrial aggregation patterns and activity in human oocytes and preimplantation embryos. Hum. Reprod. 2001, 16, 909-917. [CrossRef] [PubMed]

145. Facucho-Oliveira, J.M.; Alderson, J.; Spikings, E.C.; Egginton, S.; St John, J.C. Mitochondrial DNA replication during differentiation of murine embryonic stem cells. J. Cell Sci. 2007, 120, 4025-4034. [CrossRef]

146. Prigione, A.; Adjaye, J. Modulation of mitochondrial biogenesis and bioenergetic metabolism upon in vitro and in vivo differentiation of human ES and iPS cells. Int. J. Dev. Biol. 2010, 54, 1729-1741. [CrossRef] [PubMed]

147. Lopaschuk, G.D.; Jaswal, J.S. Energy metabolic phenotype of the cardiomyocyte during development, differentiation, and postnatal maturation. J. Cardiovasc. Pharm. 2010, 56, 130-140. [CrossRef]

148. Correia, C.; Koshkin, A.; Duarte, P.; Hu, D.; Teixeira, A.; Domian, I.; Serra, M.; Alves, P.M. Distinct carbon sources affect structural and functional maturation of cardiomyocytes derived from human pluripotent stem cells. Sci. Rep. 2017, 7, 8590. [CrossRef]

149. Hu, D.; Linders, A.; Yamak, A.; Correia, C.; Kijlstra, J.D.; Garakani, A.; Xiao, L.; Milan, D.J.; van der Meer, P.; Serra, M.; et al. Metabolic Maturation of Human Pluripotent Stem Cell-Derived Cardiomyocytes by Inhibition of HIF1alpha and LDHA. Circ. Res. 2018, 123, 1066-1079. [CrossRef]

150. Ulmer, B.M.; Stoehr, A.; Schulze, M.L.; Patel, S.; Gucek, M.; Mannhardt, I.; Funcke, S.; Murphy, E.; Eschenhagen, T.; Hansen, A. Contractile Work Contributes to Maturation of Energy Metabolism in hiPSC-Derived Cardiomyocytes. Stem Cell Rep. 2018, 10, 834-847. [CrossRef] [PubMed]

151. Skulachev, V.P. Mitochondrial filaments and clusters as intracellular power-transmitting cables. Trends Biochem. Sci. 2001, 26, 23-29. [CrossRef]

152. Bassett, A.R. Editing the genome of hiPSC with CRISPR/Cas9: Disease models. Mamm. Genome 2017, 28, 348-364. [CrossRef] [PubMed]

153. De Masi, C.; Spitalieri, P.; Murdocca, M.; Novelli, G.; Sangiuolo, F. Application of CRISPR/Cas9 to human-induced pluripotent stem cells: From gene editing to drug discovery. Hum. Genom. 2020, 14, 25. [CrossRef] [PubMed]

154. Hockemeyer, D.; Soldner, F.; Beard, C.; Gao, Q.; Mitalipova, M.; DeKelver, R.C.; Katibah, G.E.; Amora, R.; Boydston, E.A.; Zeitler, B.; et al. Efficient targeting of expressed and silent genes in human ESCs and iPSCs using zinc-finger nucleases. Nat. Biotechnol. 2009, 27, 851-857. [CrossRef] [PubMed]

155. Zou, J.; Maeder, M.L.; Mali, P.; Pruett-Miller, S.M.; Thibodeau-Beganny, S.; Chou, B.K.; Chen, G.; Ye, Z.; Park, I.H.; Daley, G.Q.; et al. Gene targeting of a disease-related gene in human induced pluripotent stem and embryonic stem cells. Cell Stem Cell 2009, 5, 97-110. [CrossRef] [PubMed]

156. Hockemeyer, D.; Wang, H.; Kiani, S.; Lai, C.S.; Gao, Q.; Cassady, J.P.; Cost, G.J.; Zhang, L.; Santiago, Y.; Miller, J.C.; et al. Genetic engineering of human pluripotent cells using TALE nucleases. Nat. Biotechnol. 2011, 29, 731-734. [CrossRef] [PubMed]

157. Perez-Pinera, P.; Kocak, D.D.; Vockley, C.M.; Adler, A.F.; Kabadi, A.M.; Polstein, L.R.; Thakore, P.I.; Glass, K.A.; Ousterout, D.G.; Leong, K.W.; et al. RNA-guided gene activation by CRISPR-Cas9-based transcription factors. Nat. Methods 2013, 10, 973-976. [CrossRef] [PubMed]

158. Shalem, O.; Sanjana, N.E.; Hartenian, E.; Shi, X.; Scott, D.A.; Mikkelson, T.; Heckl, D.; Ebert, B.L.; Root, D.E.; Doench, J.G.; et al. Genome-scale CRISPR-Cas9 knockout screening in human cells. Science 2014, 343, 84-87. [CrossRef]

159. Jinek, M.; Chylinski, K.; Fonfara, I.; Hauer, M.; Doudna, J.A.; Charpentier, E. A programmable dual-RNA-guided DNA endonuclease in adaptive bacterial immunity. Science 2012, 337, 816-821. [CrossRef] [PubMed]

160. Gaj, T.; Gersbach, C.A.; Barbas, C.F., 3rd. ZFN, TALEN, and CRISPR/Cas-based methods for genome engineering. Trends Biotechnol. 2013, 31, 397-405. [CrossRef]

161. Liu, M.; Rehman, S.; Tang, X.; Gu, K.; Fan, Q.; Chen, D.; Ma, W. Methodologies for Improving HDR Efficiency. Front. Genet. 2019, 9, 1-9. [CrossRef] [PubMed]

162. Anders, C.; Niewoehner, O.; Duerst, A.; Jinek, M. Structural basis of PAM-dependent target DNA recognition by the Cas9 endonuclease. Nature 2014, 513, 569-573. [CrossRef] [PubMed]

163. Gasiunas, G.; Siksnys, V. RNA-dependent DNA endonuclease Cas9 of the CRISPR system: Holy Grail of genome editing? Trends Microbiol. 2013, 21, 562-567. [CrossRef] 
164. Komor, A.C.; Kim, Y.B.; Packer, M.S.; Zuris, J.A.; Liu, D.R. Programmable editing of a target base in genomic DNA without double-stranded DNA cleavage. Nature 2016, 533, 420-424. [CrossRef]

165. Kim, K.; Doi, A.; Wen, B.; Ng, K.; Zhao, R.; Cahan, P.; Kim, J.; Aryee, M.J.; Ji, H.; Ehrlich, L.I.; et al. Epigenetic memory in induced pluripotent stem cells. Nature 2010, 467, 285-290. [CrossRef] [PubMed]

166. Scesa, G.; Adami, R.; Bottai, D. iPSC Preparation and Epigenetic Memory: Does the Tissue Origin Matter? Cells 2021, 10, 1470-1489. [CrossRef] [PubMed]

167. Carcamo-Orive, I.; Hoffman, G.E.; Cundiff, P.; Beckmann, N.D.; D’Souza, S.L.; Knowles, J.W.; Patel, A.; Papatsenko, D.; Abbasi, F.; Reaven, G.M.; et al. Analysis of Transcriptional Variability in a Large Human iPSC Library Reveals Genetic and Non-genetic Determinants of Heterogeneity. Cell Stem Cell 2017, 20, 518-532.e519. [CrossRef]

168. DeBoever, C.; Li, H.; Jakubosky, D.; Benaglio, P.; Reyna, J.; Olson, K.M.; Huang, H.; Biggs, W.; Sandoval, E.; D’Antonio, M.; et al. Large-Scale Profiling Reveals the Influence of Genetic Variation on Gene Expression in Human Induced Pluripotent Stem Cells. Cell Stem Cell 2017, 20, 533-546.e537. [CrossRef] [PubMed]

169. Karakikes, I.; Ameen, M.; Termglinchan, V.; Wu, J.C. Human induced pluripotent stem cell-derived cardiomyocytes: Insights into molecular, cellular, and functional phenotypes. Circ. Res. 2015, 117, 80-88. [CrossRef] [PubMed]

170. Marczenke, M.; Piccini, I.; Mengarelli, I.; Fell, J.; Röpke, A.; Seebohm, G.; Verkerk, A.O.; Greber, B. Cardiac Subtype-Specific Modeling of K(v)1.5 Ion Channel Deficiency Using Human Pluripotent Stem Cells. Front. Physiol. 2017, 8, 469. [CrossRef]

171. Brandão, K.O.; van den Brink, L.; Miller, D.C.; Grandela, C.; van Meer, B.J.; Mol, M.P.H.; de Korte, T.; Tertoolen, L.G.J.; Mummery, C.L.; Sala, L.; et al. Isogenic Sets of hiPSC-CMs Harboring Distinct KCNH2 Mutations Differ Functionally and in Susceptibility to Drug-Induced Arrhythmias. Stem Cell Rep. 2020, 15, 1127-1139. [CrossRef] [PubMed]

172. Guo, F.; Sun, Y.; Wang, X.; Wang, H.; Wang, J.; Gong, T.; Chen, X.; Zhang, P.; Su, L.; Fu, G.; et al. Patient-Specific and GeneCorrected Induced Pluripotent Stem Cell-Derived Cardiomyocytes Elucidate Single-Cell Phenotype of Short QT Syndrome. Circ. Res. 2019, 124, 66-78. [CrossRef]

173. Chadwick, A.C.; Musunuru, K. Genome Editing for the Study of Cardiovascular Diseases. Curr. Cardiol. Rep. 2017, 19, 22. [CrossRef] [PubMed]

174. Li, H.; Yang, Y.; Hong, W.; Huang, M.; Wu, M.; Zhao, X. Applications of genome editing technology in the targeted therapy of human diseases: Mechanisms, advances and prospects. Signal. Transduct. Target. Ther. 2020, 5, 1. [CrossRef] [PubMed]

175. Motta, B.M.; Pramstaller, P.P.; Hicks, A.A.; Rossini, A. The Impact of CRISPR/Cas9 Technology on Cardiac Research: From Disease Modelling to Therapeutic Approaches. Stem Cells Int. 2017, 2017, 8960236. [CrossRef] [PubMed]

176. Matsa, E.; Dixon, J.E.; Medway, C.; Georgiou, O.; Patel, M.J.; Morgan, K.; Kemp, P.J.; Staniforth, A.; Mellor, I.; Denning, C. Allelespecific RNA interference rescues the long-QT syndrome phenotype in human-induced pluripotency stem cell cardiomyocytes. Eur. Heart J. 2014, 35, 1078-1087. [CrossRef]

177. Kelly, M.; Semsarian, C. Multiple mutations in genetic cardiovascular disease: A marker of disease severity? Circ. Cardiovasc. Genet. 2009, 2, 182-190. [CrossRef]

178. Mullen, M.; Zhang, A.; Lui, G.K.; Romfh, A.W.; Rhee, J.-W.; Wu, J.C. Race and Genetics in Congenital Heart Disease: Application of iPSCs, Omics, and Machine Learning Technologies. Front. Cardiovasc. Med. 2021, 8, 1-19. [CrossRef] [PubMed]

179. Paik, D.T.; Chandy, M.; Wu, J.C. Patient and Disease-Specific Induced Pluripotent Stem Cells for Discovery of Personalized Cardiovascular Drugs and Therapeutics. Pharm. Rev. 2020, 72, 320-342. [CrossRef]

180. Musunuru, K.; Sheikh, F.; Gupta, R.M.; Houser, S.R.; Maher, K.O.; Milan, D.J.; Terzic, A.; Wu, J.C. Induced Pluripotent Stem Cells for Cardiovascular Disease Modeling and Precision Medicine: A Scientific Statement From the American Heart Association. Circ. Genom Precis. Med. 2018, 11, e000043. [CrossRef] [PubMed]

181. Chun, Y.W.; Durbin, M.D.; Hong, C.C. Genome Editing and Induced Pluripotent Stem Cell Technologies for Personalized Study of Cardiovascular Diseases. Curr. Cardiol. Rep. 2018, 20, 38. [CrossRef]

182. Pourrier, M.; Fedida, D. The Emergence of Human Induced Pluripotent Stem Cell-Derived Cardiomyocytes (hiPSC-CMs) as a Platform to Model Arrhythmogenic Diseases. Int. J. Mol. Sci. 2020, 21, 657-684. [CrossRef]

183. Prajapati, C.; Ojala, M.; Lappi, H.; Aalto-Setälä, K.; Pekkanen-Mattila, M. Electrophysiological evaluation of human induced pluripotent stem cell-derived cardiomyocytes obtained by different methods. Stem Cell Res. 2021, 51, 102176. [CrossRef] [PubMed]

184. Carvajal-Vergara, X.; Sevilla, A.; D’Souza, S.L.; Ang, Y.S.; Schaniel, C.; Lee, D.F.; Yang, L.; Kaplan, A.D.; Adler, E.D.; Rozov, R.; et al. Patient-specific induced pluripotent stem-cell-derived models of LEOPARD syndrome. Nature 2010, 465, 808-812. [CrossRef] [PubMed]

185. Limongelli, G.; Pacileo, G.; Russo, M.G.; Sarkozy, A.; Felicetti, M.; Di Salvo, G.; Morelli, C.; Calabrò, P.; Paladini, D.; Marino, B.; et al. Severe, early onset hypertrophic cardiomyopathy in a family with LEOPARD syndrome. J. Prenat. Med. 2008, 2, $24-26$.

186. Adamcova, M.; Skarkova, V.; Seifertova, J.; Rudolf, E. Cardiac Troponins are Among Targets of Doxorubicin-Induced Cardiotoxicity in hiPCS-CMs. Int. J. Mol. Sci. 2019, 20, 2638-2651. [CrossRef] [PubMed]

187. Lu, Y.; Bu, M.; Yun, H. Sevoflurane prevents hypoxia/reoxygenation-induced cardiomyocyte apoptosis by inhibiting PI3KC3mediated autophagy. Hum. Cell 2019, 32, 150-159. [CrossRef] [PubMed]

188. Naftali-Shani, N.; Molotski, N.; Nevo-Caspi, Y.; Arad, M.; Kuperstein, R.; Amit, U.; Huber, I.; Zeltzer, L.A.; Levich, A.; Abbas, H.; et al. Modeling Peripartum Cardiomyopathy With Human Induced Pluripotent Stem Cells Reveals Distinctive Abnormal Function of Cardiomyocytes. Circulation 2018, 138, 2721-2723. [CrossRef] [PubMed] 
189. Bekhite, M.; Gonzalez-Delgado, A.; Hubner, S.; Haxhikadrija, P.; Kretzschmar, T.; Muller, T.; Wu, J.M.F.; Bekfani, T.; Franz, M.; Wartenberg, M.; et al. The role of ceramide accumulation in human induced pluripotent stem cell-derived cardiomyocytes on mitochondrial oxidative stress and mitophagy. Free Radic. Biol. Med. 2021, 167, 66-80. [CrossRef]

190. Granéli, C.; Hicks, R.; Brolén, G.; Synnergren, J.; Sartipy, P. Diabetic Cardiomyopathy Modelling Using Induced Pluripotent Stem Cell Derived Cardiomyocytes: Recent Advances and Emerging Models. Stem Cell Rev. Rep. 2019, 15, 13-22. [CrossRef] [PubMed]

191. Drawnel, F.M.; Boccardo, S.; Prummer, M.; Delobel, F.; Graff, A.; Weber, M.; Gérard, R.; Badi, L.; Kam-Thong, T.; Bu, L.; et al. Disease modeling and phenotypic drug screening for diabetic cardiomyopathy using human induced pluripotent stem cells. Cell Rep. 2014, 9, 810-821. [CrossRef] [PubMed]

192. Ng, K.M.; Lau, Y.M.; Dhandhania, V.; Cai, Z.J.; Lee, Y.K.; Lai, W.H.; Tse, H.F.; Siu, C.W. Empagliflozin Ammeliorates High Glucose Induced-Cardiac Dysfuntion in Human iPSC-Derived Cardiomyocytes. Sci. Rep. 2018, 8, 14872. [CrossRef] [PubMed]

193. Sharma, A.; Marceau, C.; Hamaguchi, R.; Burridge, P.W.; Rajarajan, K.; Churko, J.M.; Wu, H.; Sallam, K.I.; Matsa, E.; Sturzu, A.C.; et al. Human induced pluripotent stem cell-derived cardiomyocytes as an in vitro model for coxsackievirus B3-induced myocarditis and antiviral drug screening platform. Circ. Res. 2014, 115, 556-566. [CrossRef] [PubMed]

194. Bozzi, A.; Sayed, N.; Matsa, E.; Sass, G.; Neofytou, E.; Clemons, K.V.; Correa-Oliveira, R.; Stevens, D.A.; Wu, J.C. Using Human Induced Pluripotent Stem Cell-Derived Cardiomyocytes as a Model to Study Trypanosoma cruzi Infection. Stem Cell Rep. 2019, 12, 1232-1241. [CrossRef] [PubMed]

195. Vatta, M.; Towbin, J.A. Mutations in KCNE1 in long QT syndrome (LQTS): Insights into mechanism of LQTS and drug sensitivity? Heart Rhythm 2006, 3, 1041-1042. [CrossRef] [PubMed]

196. Moss, A.J.; Schwartz, P.J. 25th anniversary of the International Long-QT Syndrome Registry: An ongoing quest to uncover the secrets of long-QT syndrome. Circulation 2005, 111, 1199-1201. [CrossRef] [PubMed]

197. Wallace, E.; Howard, L.; Liu, M.; O’Brien, T.; Ward, D.; Shen, S.; Prendiville, T. Long QT Syndrome: Genetics and Future Perspective. Pediatr. Cardiol. 2019, 40, 1419-1430. [CrossRef]

198. Splawski, I.; Shen, J.; Timothy, K.W.; Lehmann, M.H.; Priori, S.; Robinson, J.L.; Moss, A.J.; Schwartz, P.J.; Towbin, J.A.; Vincent, G.M.; et al. Spectrum of mutations in long-QT syndrome genes. KVLQT1, HERG, SCN5A, KCNE1, and KCNE2. Circulation 2000, 102, 1178-1185. [CrossRef]

199. Ono, M.; Burgess, D.E.; Schroder, E.A.; Elayi, C.S.; Anderson, C.L.; January, C.T.; Sun, B.; Immadisetty, K.; Kekenes-Huskey, P.M.; Delisle, B.P. Long QT Syndrome Type 2: Emerging Strategies for Correcting Class 2 KCNH2 (hERG) Mutations and Identifying New Patients. Biomolecules 2020, 10, 1144-1159. [CrossRef] [PubMed]

200. Giudicessi, J.R.; Wilde, A.A.M.; Ackerman, M.J. The genetic architecture of long QT syndrome: A critical reappraisal. Trends Cardiovasc. Med. 2018, 28, 453-464. [CrossRef]

201. Singh, M.; Morin, D.P.; Link, M.S. Sudden cardiac death in Long QT syndrome (LQTS), Brugada syndrome, and catecholaminergic polymorphic ventricular tachycardia (CPVT). Prog. Cardiovasc. Dis. 2019, 62, 227-234. [CrossRef] [PubMed]

202. Kirchhof, P.; Eckardt, L.; Franz, M.R.; Mönnig, G.; Loh, P.; Wedekind, H.; Schulze-Bahr, E.; Breithardt, G.; Haverkamp, W. Prolonged atrial action potential durations and polymorphic atrial tachyarrhythmias in patients with long QT syndrome. J. Cardiovasc. Electrophysiol. 2003, 14, 1027-1033. [CrossRef]

203. Ma, D.; Wei, H.; Lu, J.; Huang, D.; Liu, Z.; Loh, L.J.; Islam, O.; Liew, R.; Shim, W.; Cook, S.A. Characterization of a novel KCNQ1 mutation for type 1 long QT syndrome and assessment of the therapeutic potential of a novel IKs activator using patient-specific induced pluripotent stem cell-derived cardiomyocytes. Stem Cell Res. Ther. 2015, 6, 39. [CrossRef]

204. Wei, H.; Wu, J.; Liu, Z. Studying KCNQ1 Mutation and Drug Response in Type 1 Long QT Syndrome Using Patient-Specific Induced Pluripotent Stem Cell-Derived Cardiomyocytes. Methods Mol. Biol. 2018, 1684, 7-28. [CrossRef] [PubMed]

205. Itzhaki, I.; Maizels, L.; Huber, I.; Zwi-Dantsis, L.; Caspi, O.; Winterstern, A.; Feldman, O.; Gepstein, A.; Arbel, G.; Hammerman, H.; et al. Modelling the long QT syndrome with induced pluripotent stem cells. Nature 2011, 471, 225-229. [CrossRef] [PubMed]

206. Yazawa, M.; Hsueh, B.; Jia, X.; Pasca, A.M.; Bernstein, J.A.; Hallmayer, J.; Dolmetsch, R.E. Using induced pluripotent stem cells to investigate cardiac phenotypes in Timothy syndrome. Nature 2011, 471, 230-234. [CrossRef] [PubMed]

207. Song, L.; Park, S.E.; Isseroff, Y.; Morikawa, K.; Yazawa, M. Inhibition of CDK5 Alleviates the Cardiac Phenotypes in Timothy Syndrome. Stem Cell Rep. 2017, 9, 50-57. [CrossRef] [PubMed]

208. Moretti, A.; Bellin, M.; Welling, A.; Jung, C.B.; Lam, J.T.; Bott-Flügel, L.; Dorn, T.; Goedel, A.; Höhnke, C.; Hofmann, F.; et al. Patient-specific induced pluripotent stem-cell models for long-QT syndrome. N. Engl. J. Med. 2010, 363, 1397-1409. [CrossRef] [PubMed]

209. Rocchetti, M.; Sala, L.; Dreizehnter, L.; Crotti, L.; Sinnecker, D.; Mura, M.; Pane, L.S.; Altomare, C.; Torre, E.; Mostacciuolo, G.; et al. Elucidating arrhythmogenic mechanisms of long-QT syndrome CALM1-F142L mutation in patient-specific induced pluripotent stem cell-derived cardiomyocytes. Cardiovasc. Res. 2017, 113, 531-541. [CrossRef]

210. Yamamoto, Y.; Makiyama, T.; Harita, T.; Sasaki, K.; Wuriyanghai, Y.; Hayano, M.; Nishiuchi, S.; Kohjitani, H.; Hirose, S.; Chen, J.; et al. Allele-specific ablation rescues electrophysiological abnormalities in a human iPS cell model of long-QT syndrome with a CALM2 mutation. Hum. Mol. Genet. 2017, 26, 1670-1677. [CrossRef] [PubMed]

211. Hayano, M.; Makiyama, T.; Kamakura, T.; Watanabe, H.; Sasaki, K.; Funakoshi, S.; Wuriyanghai, Y.; Nishiuchi, S.; Harita, T.; Yamamoto, Y.; et al. Development of a Patient-Derived Induced Pluripotent Stem Cell Model for the Investigation of SCN5A-D1275N-Related Cardiac Sodium Channelopathy. Circ. J. 2017, 81, 1783-1791. [CrossRef] [PubMed] 
212. Veerman, C.C.; Mengarelli, I.; Guan, K.; Stauske, M.; Barc, J.; Tan, H.L.; Wilde, A.A.M.; Verkerk, A.O.; Bezzina, C.R. hiPSC-derived cardiomyocytes from Brugada Syndrome patients without identified mutations do not exhibit clear cellular electrophysiological abnormalities. Sci. Rep. 2016, 6, 30967. [CrossRef] [PubMed]

213. Sasaki, K.; Makiyama, T.; Yoshida, Y.; Wuriyanghai, Y.; Kamakura, T.; Nishiuchi, S.; Hayano, M.; Harita, T.; Yamamoto, Y.; Kohjitani, H.; et al. Patient-Specific Human Induced Pluripotent Stem Cell Model Assessed with Electrical Pacing Validates S107 as a Potential Therapeutic Agent for Catecholaminergic Polymorphic Ventricular Tachycardia. PLoS ONE 2016, 11, e0164795. [CrossRef]

214. Seidman, C.E.; Seidman, J.G. Identifying sarcomere gene mutations in hypertrophic cardiomyopathy: A personal history. Circ. Res. 2011, 108, 743-750. [CrossRef] [PubMed]

215. Smith, J.G.W.; Owen, T.; Bhagwan, J.R.; Mosqueira, D.; Scott, E.; Mannhardt, I.; Patel, A.; Barriales-Villa, R.; Monserrat, L.; Hansen, A.; et al. Isogenic Pairs of hiPSC-CMs with Hypertrophic Cardiomyopathy/LVNC-Associated ACTC1 E99K Mutation Unveil Differential Functional Deficits. Stem Cell Rep. 2018, 11, 1226-1243. [CrossRef]

216. Phelan, D.G.; Anderson, D.J.; Howden, S.E.; Wong, R.C.; Hickey, P.F.; Pope, K.; Wilson, G.R.; Pébay, A.; Davis, A.M.; Petrou, S.; et al. ALPK3-deficient cardiomyocytes generated from patient-derived induced pluripotent stem cells and mutant human embryonic stem cells display abnormal calcium handling and establish that ALPK3 deficiency underlies familial cardiomyopathy. Eur. Heart J. 2016, 37, 2586-2590. [CrossRef] [PubMed]

217. Josowitz, R.; Mulero-Navarro, S.; Rodriguez, N.A.; Falce, C.; Cohen, N.; Ullian, E.M.; Weiss, L.A.; Rauen, K.A.; Sobie, E.A.; Gelb, B.D. Autonomous and Non-autonomous Defects Underlie Hypertrophic Cardiomyopathy in BRAF-Mutant hiPSC-Derived Cardiomyocytes. Stem Cell Rep. 2016, 7, 355-369. [CrossRef]

218. Klein, S.; Dvornik, J.L.; Yarrabothula, A.R.; Schaniel, C. A Marfan syndrome human induced pluripotent stem cell line with a heterozygous FBN1 c.4082G>A mutation, ISMMSi002-B, for disease modeling. Stem Cell Res. 2017, 23, 73-76. [CrossRef] [PubMed]

219. Hick, A.; Wattenhofer-Donzé, M.; Chintawar, S.; Tropel, P.; Simard, J.P.; Vaucamps, N.; Gall, D.; Lambot, L.; André, C.; Reutenauer, L.; et al. Neurons and cardiomyocytes derived from induced pluripotent stem cells as a model for mitochondrial defects in Friedreich's ataxia. Dis. Model. Mech 2013, 6, 608-621. [CrossRef]

220. Chou, S.J.; Yu, W.C.; Chang, Y.L.; Chen, W.Y.; Chang, W.C.; Chien, Y.; Yen, J.C.; Liu, Y.Y.; Chen, S.J.; Wang, C.Y.; et al. Energy utilization of induced pluripotent stem cell-derived cardiomyocyte in Fabry disease. Int. J. Cardiol. 2017, 232, 255-263. [CrossRef]

221. Li, S.; Pan, H.; Tan, C.; Sun, Y.; Song, Y.; Zhang, X.; Yang, W.; Wang, X.; Li, D.; Dai, Y.; et al. Mitochondrial Dysfunctions Contribute to Hypertrophic Cardiomyopathy in Patient iPSC-Derived Cardiomyocytes with MT-RNR2 Mutation. Stem Cell Rep. 2018, 10, 808-821. [CrossRef]

222. Wu, H.; Yang, H.; Rhee, J.W.; Zhang, J.Z.; Lam, C.K.; Sallam, K.; Chang, A.C.Y.; Ma, N.; Lee, J.; Zhang, H.; et al. Modelling diastolic dysfunction in induced pluripotent stem cell-derived cardiomyocytes from hypertrophic cardiomyopathy patients. Eur. Heart J. 2019, 40, 3685-3695. [CrossRef] [PubMed]

223. Dementyeva, E.V.; Medvedev, S.P.; Kovalenko, V.R.; Vyatkin, Y.V.; Kretov, E.I.; Slotvitsky, M.M.; Shtokalo, D.N.; Pokushalov, E.A.; Zakian, S.M. Applying Patient-Specific Induced Pluripotent Stem Cells to Create a Model of Hypertrophic Cardiomyopathy. Biochemistry 2019, 84, 291-298. [CrossRef] [PubMed]

224. Dambrot, C.; Braam, S.R.; Tertoolen, L.G.; Birket, M.; Atsma, D.E.; Mummery, C.L. Serum supplemented culture medium masks hypertrophic phenotypes in human pluripotent stem cell derived cardiomyocytes. J. Cell Mol. Med. 2014, 18, 1509-1518. [CrossRef] [PubMed]

225. Birket, M.J.; Ribeiro, M.C.; Kosmidis, G.; Ward, D.; Leitoguinho, A.R.; van de Pol, V.; Dambrot, C.; Devalla, H.D.; Davis, R.P.; Mastroberardino, P.G.; et al. Contractile Defect Caused by Mutation in MYBPC3 Revealed under Conditions Optimized for Human PSC-Cardiomyocyte Function. Cell Rep. 2015, 13, 733-745. [CrossRef] [PubMed]

226. Holliday, M.; Ross, S.B.; Lim, S.; Semsarian, C. Generation of an induced pluripotent stem cell line from a hypertrophic cardiomyopathy patient with a pathogenic myosin binding protein C (MYBPC3) p.Arg502Trp mutation. Stem Cell Res. 2018, 33, 56-59. [CrossRef] [PubMed]

227. Seeger, T.; Shrestha, R.; Lam, C.K.; Chen, C.; McKeithan, W.L.; Lau, E.; Wnorowski, A.; McMullen, G.; Greenhaw, M.; Lee, J.; et al. A Premature Termination Codon Mutation in MYBPC3 Causes Hypertrophic Cardiomyopathy via Chronic Activation of Nonsense-Mediated Decay. Circulation 2019, 139, 799-811. [CrossRef]

228. Ojala, M.; Prajapati, C.; Pölönen, R.P.; Rajala, K.; Pekkanen-Mattila, M.; Rasku, J.; Larsson, K.; Aalto-Setälä, K. Mutation-Specific Phenotypes in hiPSC-Derived Cardiomyocytes Carrying Either Myosin-Binding Protein C Or $\alpha$-Tropomyosin Mutation for Hypertrophic Cardiomyopathy. Stem Cells Int. 2016, 2016, 1684792. [CrossRef]

229. Prajapati, C.; Ojala, M.; Aalto-Setälä, K. Divergent effects of adrenaline in human induced pluripotent stem cell-derived cardiomyocytes obtained from hypertrophic cardiomyopathy. Dis. Model. Mech. 2018, 11. [CrossRef] [PubMed]

230. Prondzynski, M.; Krämer, E.; Laufer, S.D.; Shibamiya, A.; Pless, O.; Flenner, F.; Müller, O.J.; Münch, J.; Redwood, C.; Hansen, A.; et al. Evaluation of MYBPC3 trans-Splicing and Gene Replacement as Therapeutic Options in Human iPSC-Derived Cardiomyocytes. Mol. Ther. Nucleic Acids 2017, 7, 475-486. [CrossRef] [PubMed]

231. Viswanathan, S.K.; Puckelwartz, M.J.; Mehta, A.; Ramachandra, C.J.A.; Jagadeesan, A.; Fritsche-Danielson, R.; Bhat, R.V.; Wong, P.; Kandoi, S.; Schwanekamp, J.A.; et al. Association of Cardiomyopathy With MYBPC3 D389V and MYBPC $3 \triangle 25 b p I n t r o n i c$ Deletion in South Asian Descendants. JAMA Cardiol. 2018, 3, 481-488. [CrossRef] 
232. Mosqueira, D.; Mannhardt, I.; Bhagwan, J.R.; Lis-Slimak, K.; Katili, P.; Scott, E.; Hassan, M.; Prondzynski, M.; Harmer, S.C.; Tinker, A.; et al. CRISPR/Cas9 editing in human pluripotent stem cell-cardiomyocytes highlights arrhythmias, hypocontractility, and energy depletion as potential therapeutic targets for hypertrophic cardiomyopathy. Eur. Heart J. 2018, 39, 3879-3892. [CrossRef] [PubMed]

233. Ross, S.B.; Fraser, S.T.; Nowak, N.; Semsarian, C. Generation of induced pluripotent stem cells (iPSCs) from a hypertrophic cardiomyopathy patient with the pathogenic variant p.Val698Ala in beta-myosin heavy chain (MYH7) gene. Stem Cell Res. 2017, 20, 88-90. [CrossRef] [PubMed]

234. Yang, K.C.; Breitbart, A.; De Lange, W.J.; Hofsteen, P.; Futakuchi-Tsuchida, A.; Xu, J.; Schopf, C.; Razumova, M.V.; Jiao, A.; Boucek, R.; et al. Novel Adult-Onset Systolic Cardiomyopathy Due to MYH7 E848G Mutation in Patient-Derived Induced Pluripotent Stem Cells. JACC Basic Transl. Sci. 2018, 3, 728-740. [CrossRef]

235. Pioner, J.M.; Racca, A.W.; Klaiman, J.M.; Yang, K.C.; Guan, X.; Pabon, L.; Muskheli, V.; Zaunbrecher, R.; Macadangdang, J.; Jeong, M.Y.; et al. Isolation and Mechanical Measurements of Myofibrils from Human Induced Pluripotent Stem Cell-Derived Cardiomyocytes. Stem Cell Rep. 2016, 6, 885-896. [CrossRef] [PubMed]

236. Lan, F.; Lee, A.S.; Liang, P.; Sanchez-Freire, V.; Nguyen, P.K.; Wang, L.; Han, L.; Yen, M.; Wang, Y.; Sun, N.; et al. Abnormal calcium handling properties underlie familial hypertrophic cardiomyopathy pathology in patient-specific induced pluripotent stem cells. Cell Stem Cell 2013, 12, 101-113. [CrossRef] [PubMed]

237. Han, L.; Li, Y.; Tchao, J.; Kaplan, A.D.; Lin, B.; Li, Y.; Mich-Basso, J.; Lis, A.; Hassan, N.; London, B.; et al. Study familial hypertrophic cardiomyopathy using patient-specific induced pluripotent stem cells. Cardiovasc. Res. 2014, 104, 258-269. [CrossRef]

238. Zhou, W.; Bos, J.M.; Ye, D.; Tester, D.J.; Hrstka, S.; Maleszewski, J.J.; Ommen, S.R.; Nishimura, R.A.; Schaff, H.V.; Kim, C.S.; et al. Induced Pluripotent Stem Cell-Derived Cardiomyocytes from a Patient with MYL2-R58Q-Mediated Apical Hypertrophic Cardiomyopathy Show Hypertrophy, Myofibrillar Disarray, and Calcium Perturbations. J. Cardiovasc. Transl. Res. 2019, 12, 394-403. [CrossRef] [PubMed]

239. Ma, N.; Zhang, J.Z.; Itzhaki, I.; Zhang, S.L.; Chen, H.; Haddad, F.; Kitani, T.; Wilson, K.D.; Tian, L.; Shrestha, R.; et al. Determining the Pathogenicity of a Genomic Variant of Uncertain Significance Using CRISPR/Cas9 and Human-Induced Pluripotent Stem Cells. Circulation 2018, 138, 2666-2681. [CrossRef] [PubMed]

240. Ben Jehuda, R.; Eisen, B.; Shemer, Y.; Mekies, L.N.; Szantai, A.; Reiter, I.; Cui, H.; Guan, K.; Haron-Khun, S.; Freimark, D.; et al. CRISPR correction of the PRKAG2 gene mutation in the patient's induced pluripotent stem cell-derived cardiomyocytes eliminates electrophysiological and structural abnormalities. Heart Rhythm 2018, 15, 267-276. [CrossRef] [PubMed]

241. Hinson, J.T.; Chopra, A.; Lowe, A.; Sheng, C.C.; Gupta, R.M.; Kuppusamy, R.; O'Sullivan, J.; Rowe, G.; Wakimoto, H.; Gorham, J.; et al. Integrative Analysis of PRKAG2 Cardiomyopathy iPS and Microtissue Models Identifies AMPK as a Regulator of Metabolism, Survival, and Fibrosis. Cell Rep. 2017, 19, 2410. [CrossRef] [PubMed]

242. Li, R.; Baskfield, A.; Lin, Y.; Beers, J.; Zou, J.; Liu, C.; Jaffré, F.; Roberts, A.E.; Ottinger, E.A.; Kontaridis, M.I.; et al. Generation of an induced pluripotent stem cell line (TRNDi003-A) from a Noonan syndrome with multiple lentigines (NSML) patient carrying a p.Q510P mutation in the PTPN11 gene. Stem Cell Res. 2019, 34, 101374. [CrossRef] [PubMed]

243. Hallas, T.; Eisen, B.; Shemer, Y.; Ben Jehuda, R.; Mekies, L.N.; Naor, S.; Schick, R.; Eliyahu, S.; Reiter, I.; Vlodavsky, E.; et al. Investigating the cardiac pathology of SCO2-mediated hypertrophic cardiomyopathy using patients induced pluripotent stem cell-derived cardiomyocytes. J. Cell Mol. Med. 2018, 22, 913-925. [CrossRef] [PubMed]

244. Karakikes, I.; Termglinchan, V.; Cepeda, D.A.; Lee, J.; Diecke, S.; Hendel, A.; Itzhaki, I.; Ameen, M.; Shrestha, R.; Wu, H.; et al. A Comprehensive TALEN-Based Knockout Library for Generating Human-Induced Pluripotent Stem Cell-Based Models for Cardiovascular Diseases. Circ. Res. 2017, 120, 1561-1571. [CrossRef]

245. Garg, P.; Garg, V.; Shrestha, R.; Sanguinetti, M.C.; Kamp, T.J.; Wu, J.C. Human Induced Pluripotent Stem Cell-Derived Cardiomyocytes as Models for Cardiac Channelopathies: A Primer for Non-Electrophysiologists. Circ. Res. 2018, 123, 224-243. [CrossRef] [PubMed]

246. Ciarambino, T.; Menna, G.; Sansone, G.; Giordano, M. Cardiomyopathies: An Overview. Int. J. Mol. Sci. 2021, 22. [CrossRef]

247. Lakdawala, N.K.; Winterfield, J.R.; Funke, B.H. Dilated cardiomyopathy. Circ. Arrhythm. Electrophysiol. 2013, 6, 228-237. [CrossRef] [PubMed]

248. Jefferies, J.L.; Towbin, J.A. Dilated cardiomyopathy. Lancet 2010, 375, 752-762. [CrossRef]

249. Kellermayer, D.; Smith, J.E., 3rd; Granzier, H. Titin mutations and muscle disease. Pflug. Arch. 2019, 471, 673-682. [CrossRef]

250. Hershberger, R.E.; Morales, A. LMNA-Related Dilated Cardiomyopathy. In GeneReviews $\left({ }^{\circledR}\right)$; Adam, M.P., Ardinger, H.H., Pagon, R.A., Wallace, S.E., Bean, L.J.H., Mirzaa, G., Amemiya, A., Eds.; University of Washington: Seattle, WA, USA, 1993.

251. Zhao, Y.; Feng, Y.; Zhang, Y.M.; Ding, X.X.; Song, Y.Z.; Zhang, A.M.; Liu, L.; Zhang, H.; Ding, J.H.; Xia, X.S. Targeted nextgeneration sequencing of candidate genes reveals novel mutations in patients with dilated cardiomyopathy. Int. J. Mol. Med. 2015, 36, 1479-1486. [CrossRef]

252. Olson, T.M.; Michels, V.V.; Ballew, J.D.; Reyna, S.P.; Karst, M.L.; Herron, K.J.; Horton, S.C.; Rodeheffer, R.J.; Anderson, J.L. Sodium channel mutations and susceptibility to heart failure and atrial fibrillation. JAMA 2005, 293, 447-454. [CrossRef]

253. Ehlermann, P.; Weichenhan, D.; Zehelein, J.; Steen, H.; Pribe, R.; Zeller, R.; Lehrke, S.; Zugck, C.; Ivandic, B.T.; Katus, H.A. Adverse events in families with hypertrophic or dilated cardiomyopathy and mutations in the MYBPC3 gene. BMC Med. Genet. 2008, 9, 95. [CrossRef] [PubMed] 
254. Zhao, Y.; Cao, H.; Song, Y.; Feng, Y.; Ding, X.; Pang, M.; Zhang, Y.; Zhang, H.; Ding, J.; Xia, X. Identification of novel mutations including a double mutation in patients with inherited cardiomyopathy by a targeted sequencing approach using the Ion Torrent PGM system. Int. J. Mol. Med. 2016, 37, 1511-1520. [CrossRef] [PubMed]

255. Tse, H.F.; Ho, J.C.; Choi, S.W.; Lee, Y.K.; Butler, A.W.; Ng, K.M.; Siu, C.W.; Simpson, M.A.; Lai, W.H.; Chan, Y.C.; et al. Patient-specific induced-pluripotent stem cells-derived cardiomyocytes recapitulate the pathogenic phenotypes of dilated cardiomyopathy due to a novel DES mutation identified by whole exome sequencing. Hum. Mol. Genet. 2013, 22, $1395-1403$. [CrossRef]

256. El-Battrawy, I.; Zhao, Z.; Lan, H.; Li, X.; Yücel, G.; Lang, S.; Sattler, K.; Schünemann, J.D.; Zimmermann, W.H.; Cyganek, L.; et al. Ion Channel Dysfunctions in Dilated Cardiomyopathy in Limb-Girdle Muscular Dystrophy. Circ. Genom Precis. Med. 2018, 11, e001893. [CrossRef] [PubMed]

257. Shah, D.; Virtanen, L.; Prajapati, C.; Kiamehr, M.; Gullmets, J.; West, G.; Kreutzer, J.; Pekkanen-Mattila, M.; Heliö, T.; Kallio, P.; et al. Modeling of LMNA-Related Dilated Cardiomyopathy Using Human Induced Pluripotent Stem Cells. Cells 2019, 8, 594-615. [CrossRef]

258. Ho, J.C.; Zhou, T.; Lai, W.H.; Huang, Y.; Chan, Y.C.; Li, X.; Wong, N.L.; Li, Y.; Au, K.W.; Guo, D.; et al. Generation of induced pluripotent stem cell lines from 3 distinct laminopathies bearing heterogeneous mutations in lamin A/C. Aging 2011, 3, 380-390. [CrossRef] [PubMed]

259. Siu, C.W.; Lee, Y.K.; Ho, J.C.; Lai, W.H.; Chan, Y.C.; Ng, K.M.; Wong, L.Y.; Au, K.W.; Lau, Y.M.; Zhang, J.; et al. Modeling of lamin A/C mutation premature cardiac aging using patient-specific induced pluripotent stem cells. Aging 2012, 4, 803-822. [CrossRef] [PubMed]

260. Lee, Y.K.; Lau, Y.M.; Cai, Z.J.; Lai, W.H.; Wong, L.Y.; Tse, H.F.; Ng, K.M.; Siu, C.W. Modeling Treatment Response for Lamin A/C Related Dilated Cardiomyopathy in Human Induced Pluripotent Stem Cells. J. Am. Heart Assoc. 2017, 6, 5677-5712. [CrossRef] [PubMed]

261. Salvarani, N.; Crasto, S.; Miragoli, M.; Bertero, A.; Paulis, M.; Kunderfranco, P.; Serio, S.; Forni, A.; Lucarelli, C.; Dal Ferro, M.; et al. The K219T-Lamin mutation induces conduction defects through epigenetic inhibition of SCN5A in human cardiac laminopathy. Nat. Commun 2019, 10, 2267. [CrossRef] [PubMed]

262. Davis, J.; Davis, L.C.; Correll, R.N.; Makarewich, C.A.; Schwanekamp, J.A.; Moussavi-Harami, F.; Wang, D.; York, A.J.; Wu, H.; Houser, S.R.; et al. A Tension-Based Model Distinguishes Hypertrophic versus Dilated Cardiomyopathy. Cell 2016, 165, 1147-1159. [CrossRef]

263. Ceholski, D.K.; Turnbull, I.C.; Kong, C.W.; Koplev, S.; Mayourian, J.; Gorski, P.A.; Stillitano, F.; Skodras, A.A.; Nonnenmacher, M.; Cohen, N.; et al. Functional and transcriptomic insights into pathogenesis of R9C phospholamban mutation using human induced pluripotent stem cell-derived cardiomyocytes. J. Mol. Cell Cardiol. 2018, 119, 147-154. [CrossRef]

264. Karakikes, I.; Stillitano, F.; Nonnenmacher, M.; Tzimas, C.; Sanoudou, D.; Termglinchan, V.; Kong, C.W.; Rushing, S.; Hansen, J.; Ceholski, D.; et al. Correction of human phospholamban R14del mutation associated with cardiomyopathy using targeted nucleases and combination therapy. Nat. Commun. 2015, 6, 6955. [CrossRef] [PubMed]

265. Stillitano, F.; Turnbull, I.C.; Karakikes, I.; Nonnenmacher, M.; Backeris, P.; Hulot, J.S.; Kranias, E.G.; Hajjar, R.J.; Costa, K.D. Genomic correction of familial cardiomyopathy in human engineered cardiac tissues. Eur. Heart J. 2016, 37, 3282-3284. [CrossRef] [PubMed]

266. Streckfuss-Bömeke, K.; Tiburcy, M.; Fomin, A.; Luo, X.; Li, W.; Fischer, C.; Özcelik, C.; Perrot, A.; Sossalla, S.; Haas, J.; et al. Severe DCM phenotype of patient harboring RBM20 mutation S635A can be modeled by patient-specific induced pluripotent stem cell-derived cardiomyocytes. J. Mol. Cell Cardiol. 2017, 113, 9-21. [CrossRef]

267. Wyles, S.P.; Li, X.; Hrstka, S.C.; Reyes, S.; Oommen, S.; Beraldi, R.; Edwards, J.; Terzic, A.; Olson, T.M.; Nelson, T.J. Modeling structural and functional deficiencies of RBM20 familial dilated cardiomyopathy using human induced pluripotent stem cells. Hum. Mol. Genet. 2016, 25, 254-265. [CrossRef] [PubMed]

268. Sun, N.; Yazawa, M.; Liu, J.; Han, L.; Sanchez-Freire, V.; Abilez, O.J.; Navarrete, E.G.; Hu, S.; Wang, L.; Lee, A.; et al. Patientspecific induced pluripotent stem cells as a model for familial dilated cardiomyopathy. Sci. Transl. Med. 2012, 4, 130 ra147. [CrossRef]

269. Broughton, K.M.; Li, J.; Sarmah, E.; Warren, C.M.; Lin, Y.H.; Henze, M.P.; Sanchez-Freire, V.; Solaro, R.J.; Russell, B. A myosin activator improves actin assembly and sarcomere function of human-induced pluripotent stem cell-derived cardiomyocytes with a troponin T point mutation. Am. J. Physiol. Heart Circ. Physiol. 2016, 311, H107-H117. [CrossRef] [PubMed]

270. Hinson, J.T.; Chopra, A.; Nafissi, N.; Polacheck, W.J.; Benson, C.C.; Swist, S.; Gorham, J.; Yang, L.; Schafer, S.; Sheng, C.C.; et al. HEART DISEASE. Titin mutations in iPS cells define sarcomere insufficiency as a cause of dilated cardiomyopathy. Science 2015, 349, 982-986. [CrossRef]

271. Schick, R.; Mekies, L.N.; Shemer, Y.; Eisen, B.; Hallas, T.; Ben Jehuda, R.; Ben-Ari, M.; Szantai, A.; Willi, L.; Shulman, R.; et al. Functional abnormalities in induced Pluripotent Stem Cell-derived cardiomyocytes generated from titin-mutated patients with dilated cardiomyopathy. PLoS ONE 2018, 13, e0205719. [CrossRef] [PubMed]

272. Camman, M.; Joanne, P.; Agbulut, O.; Hélary, C. 3D models of dilated cardiomyopathy: Shaping the chemical, physical and topographical properties of biomaterials to mimic the cardiac extracellular matrix. Bioact. Mater. 2022, 7, 275-291. [CrossRef] 
273. Sato, Y.; Kobayashi, H.; Higuchi, T.; Shimada, Y.; Era, T.; Kimura, S.; Eto, Y.; Ida, H.; Ohashi, T. Disease modeling and lentiviral gene transfer in patient-specific induced pluripotent stem cells from late-onset Pompe disease patient. Mol. Ther. Methods Clin. Dev. 2015, 2, 15023. [CrossRef] [PubMed]

274. McKoy, G.; Protonotarios, N.; Crosby, A.; Tsatsopoulou, A.; Anastasakis, A.; Coonar, A.; Norman, M.; Baboonian, C.; Jeffery, S.; McKenna, W.J. Identification of a deletion in plakoglobin in arrhythmogenic right ventricular cardiomyopathy with palmoplantar keratoderma and woolly hair (Naxos disease). Lancet 2000, 355, 2119-2124. [CrossRef]

275. Gerull, B.; Heuser, A.; Wichter, T.; Paul, M.; Basson, C.T.; McDermott, D.A.; Lerman, B.B.; Markowitz, S.M.; Ellinor, P.T.; MacRae, C.A.; et al. Mutations in the desmosomal protein plakophilin-2 are common in arrhythmogenic right ventricular cardiomyopathy. Nat. Genet. 2004, 36, 1162-1164. [CrossRef] [PubMed]

276. Patel, D.M.; Green, K.J. Desmosomes in the heart: A review of clinical and mechanistic analyses. Cell Commun. Adhes 2014, 21, 109-128. [CrossRef]

277. Horikoshi, Y.; Yan, Y.; Terashvili, M.; Wells, C.; Horikoshi, H.; Fujita, S.; Bosnjak, Z.J.; Bai, X. Fatty Acid-Treated Induced Pluripotent Stem Cell-Derived Human Cardiomyocytes Exhibit Adult Cardiomyocyte-Like Energy Metabolism Phenotypes. Cells 2019, 8, 1095-1116. [CrossRef]

278. Feyen, D.A.M.; McKeithan, W.L.; Bruyneel, A.A.N.; Spiering, S.; Hörmann, L.; Ulmer, B.; Zhang, H.; Briganti, F.; Schweizer, M.; Hegyi, B.; et al. Metabolic Maturation Media Improve Physiological Function of Human iPSC-Derived Cardiomyocytes. Cell Rep. 2020, 32, 107925. [CrossRef]

279. Yang, X.; Rodriguez, M.; Pabon, L.; Fischer, K.A.; Reinecke, H.; Regnier, M.; Sniadecki, N.J.; Ruohola-Baker, H.; Murry, C.E. Tri-iodo-l-thyronine promotes the maturation of human cardiomyocytes-derived from induced pluripotent stem cells. J. Mol. Cell. Cardiol. 2014, 72, 296-304. [CrossRef] [PubMed]

280. Kenessey, A.; Ojamaa, K. Thyroid Hormone Stimulates Protein Synthesis in the Cardiomyocyte by Activating the Akt-mTOR and p70S6K Pathways. J. Biol. Chem. 2006, 281, 20666-20672. [CrossRef]

281. Parikh, S.S.; Blackwell, D.J.; Gomez-Hurtado, N.; Frisk, M.; Wang, L.; Kim, K.; Dahl, C.P.; Fiane, A.; Tønnessen, T.; Kryshtal, D.O.; et al. Thyroid and Glucocorticoid Hormones Promote Functional T-Tubule Development in Human-Induced Pluripotent Stem Cell-Derived Cardiomyocytes. Circ. Res. 2017, 121, 1323-1330. [CrossRef] [PubMed]

282. Chan, Y.-C.; Ting, S.; Lee, Y.-K.; Ng, K.-M.; Zhang, J.; Chen, Z.; Siu, C.-W.; Oh, S.K.W.; Tse, H.-F. Electrical Stimulation Promotes Maturation of Cardiomyocytes Derived from Human Embryonic Stem Cells. J. Cardiovasc. Transl. Res. 2013, 6, 989-999. [CrossRef] [PubMed]

283. Kroll, K.; Chabria, M.; Wang, K.; Häusermann, F.; Schuler, F.; Polonchuk, L. Electro-mechanical conditioning of human iPSCderived cardiomyocytes for translational research. Prog. Biophys. Mol. Biol. 2017, 130, 212-222. [CrossRef] [PubMed]

284. Zhang, W.; Kong, C.W.; Tong, M.H.; Chooi, W.H.; Huang, N.; Li, R.A.; Chan, B.P. Maturation of human embryonic stem cell-derived cardiomyocytes (hESC-CMs) in 3D collagen matrix: Effects of niche cell supplementation and mechanical stimulation. Acta Biomater. 2017, 49, 204-217. [CrossRef] [PubMed]

285. Huang, C.Y.; Peres Moreno Maia-Joca, R.; Ong, C.S.; Wilson, I.; DiSilvestre, D.; Tomaselli, G.F.; Reich, D.H. Enhancement of human iPSC-derived cardiomyocyte maturation by chemical conditioning in a 3D environment. J. Mol. Cell. Cardiol. 2020, 138, 1-11. [CrossRef] [PubMed]

286. Sacchetto, C.; Vitiello, L.; de Windt, L.J.; Rampazzo, A.; Calore, M. Modeling Cardiovascular Diseases with hiPSC-Derived Cardiomyocytes in 2D and 3D Cultures. Int. J. Mol. Sci. 2020, 21, 3404-3436. [CrossRef] [PubMed]

287. Pinto, A.R.; Ilinykh, A.; Ivey, M.J.; Kuwabara, J.T.; D'Antoni, M.L.; Debuque, R.; Chandran, A.; Wang, L.; Arora, K.; Rosenthal, N.A.; et al. Revisiting Cardiac Cellular Composition. Circ. Res. 2016, 118, 400-409. [CrossRef] [PubMed]

288. Zhao, X.; Xu, Z.; Xiao, L.; Shi, T.; Xiao, H.; Wang, Y.; Li, Y.; Xue, F.; Zeng, W. Review on the Vascularization of Organoids and Organoids-on-a-Chip. Front. Bioeng. Biotechnol. 2021, 9, 1-10. [CrossRef]

289. Thomas, D.; Cunningham, N.J.; Shenoy, S.; Wu, J.C. Human-induced pluripotent stem cells in cardiovascular research: Current approaches in cardiac differentiation, maturation strategies, and scalable production. Cardiovasc. Res. 2021, Online ahead of print, 1-17. [CrossRef]

290. Beauchamp, P.; Jackson, C.B.; Ozhathil, L.C.; Agarkova, I.; Galindo, C.L.; Sawyer, D.B.; Suter, T.M.; Zuppinger, C. 3D Co-culture of hiPSC-Derived Cardiomyocytes With Cardiac Fibroblasts Improves Tissue-Like Features of Cardiac Spheroids. Front. Mol. Biosci. 2020, 7, 14. [CrossRef] [PubMed]

291. Decarli, M.C.; do Amaral, R.L.F.; Dos Santos, D.P.; Tofani, L.B.; Katayama, E.; Rezende, R.A.; Silva, J.; Swiech, K.; Suazo, C.A.T.; Mota, C.; et al. Cell spheroids as a versatile research platform: Formation mechanisms, high throughput production, characterization and applications. Biofabrication 2021, 13, 032002. [CrossRef]

292. Cho, S.; Lee, C.; Skylar-Scott, M.A.; Heilshorn, S.C.; Wu, J.C. Reconstructing the heart using iPSCs: Engineering strategies and applications. J. Mol. Cell Cardiol. 2021, 157, 56-65. [CrossRef] [PubMed]

293. Rossi, G.; Broguiere, N.; Miyamoto, M.; Boni, A.; Guiet, R.; Girgin, M.; Kelly, R.G.; Kwon, C.; Lutolf, M.P. Capturing Cardiogenesis in Gastruloids. Cell Stem Cell 2021, 28, 230-240.e236. [CrossRef]

294. Zhao, D.; Lei, W.; Hu, S. Cardiac organoid - a promising perspective of preclinical model. Stem Cell Res. Ther. 2021, 12, 272. [CrossRef] [PubMed] 
295. Drakhlis, L.; Biswanath, S.; Farr, C.-M.; Lupanow, V.; Teske, J.; Ritzenhoff, K.; Franke, A.; Manstein, F.; Bolesani, E.; Kempf, H.; et al. Human heart-forming organoids recapitulate early heart and foregut development. Nat. Biotechnol. 2021, 39, 737-746. [CrossRef]

296. Lewis-Israeli, Y.R.; Wasserman, A.H.; Aguirre, A. Heart Organoids and Engineered Heart Tissues: Novel Tools for Modeling Human Cardiac Biology and Disease. Biomolecules 2021, 11, 1277. [CrossRef] [PubMed]

297. Pham, M.T.; Pollock, K.M.; Rose, M.D.; Cary, W.A.; Stewart, H.R.; Zhou, P.; Nolta, J.A.; Waldau, B. Generation of human vascularized brain organoids. NeuroReport 2018, 29, 588-593. [CrossRef] [PubMed]

298. Kitsuka, T.; Itoh, M.; Amamoto, S.; Arai, K.I.; Oyama, J.; Node, K.; Toda, S.; Morita, S.; Nishida, T.; Nakayama, K. 2-Cl-C.OXT-A stimulates contraction through the suppression of phosphodiesterase activity in human induced pluripotent stem cell-derived cardiac organoids. PLoS ONE 2019, 14, e0213114. [CrossRef]

299. Xiang, Y.; Tanaka, Y.; Patterson, B.; Kang, Y.-J.; Govindaiah, G.; Roselaar, N.; Cakir, B.; Kim, K.-Y.; Lombroso, A.P.; Hwang, S.-M.; et al. Fusion of Regionally Specified hPSC-Derived Organoids Models Human Brain Development and Interneuron Migration. Cell Stem Cell 2017, 21, 383-398.e387. [CrossRef]

300. Mannhardt, I.; Breckwoldt, K.; Letuffe-Brenière, D.; Schaaf, S.; Schulz, H.; Neuber, C.; Benzin, A.; Werner, T.; Eder, A.; Schulze, T.; et al. Human Engineered Heart Tissue: Analysis of Contractile Force. Stem Cell Rep. 2016, 7, 29-42. [CrossRef]

301. Weinberger, F.; Mannhardt, I.; Eschenhagen, T. Engineering Cardiac Muscle Tissue. Circ. Res. 2017, 120, 1487-1500. [CrossRef]

302. Tadevosyan, K.; Iglesias-García, O.; Mazo, M.M.; Prósper, F.; Raya, A. Engineering and Assessing Cardiac Tissue Complexity. Int. J. Mol. Sci. 2021, 22, 1479. [CrossRef]

303. Eschenhagen, T.; Fink, C.; Remmers, U.; Scholz, H.; Wattchow, J.; Weil, J.; Zimmermann, W.; Dohmen, H.H.; Schäfer, H.; Bishopric, N.; et al. Three-dimensional reconstitution of embryonic cardiomyocytes in a collagen matrix: A new heart muscle model system. FASEB J. 1997, 11, 683-694. [CrossRef]

304. Majid, Q.A.; Fricker, A.T.R.; Gregory, D.A.; Davidenko, N.; Hernandez Cruz, O.; Jabbour, R.J.; Owen, T.J.; Basnett, P.; Lukasiewicz, B.; Stevens, M.; et al. Natural Biomaterials for Cardiac Tissue Engineering: A Highly Biocompatible Solution. Front. Cardiovasc. Med. 2020, 7, 1-32. [CrossRef] [PubMed]

305. Roshandel, M.; Dorkoosh, F. Cardiac tissue engineering, biomaterial scaffolds, and their fabrication techniques. Polym. Adv. Technol. 2021, 32, 2290-2305. [CrossRef]

306. Liu, H.; Bolonduro, O.A.; Hu, N.; Ju, J.; Rao, A.A.; Duffy, B.M.; Huang, Z.; Black, L.D.; Timko, B.P. Heart-on-a-Chip Model with Integrated Extra- and Intracellular Bioelectronics for Monitoring Cardiac Electrophysiology under Acute Hypoxia. Nano Lett. 2020, 20, 2585-2593. [CrossRef] [PubMed]

307. Martewicz, S.; Michielin, F.; Serena, E.; Zambon, A.; Mongillo, M.; Elvassore, N. Reversible alteration of calcium dynamics in cardiomyocytes during acute hypoxia transient in a microfluidic platform. Integr. Biol. 2012, 4, 153-164. [CrossRef] [PubMed]

308. Mousavi Shaegh, S.A.; De Ferrari, F.; Zhang, Y.S.; Nabavinia, M.; Binth Mohammad, N.; Ryan, J.; Pourmand, A.; Laukaitis, E.; Banan Sadeghian, R.; Nadhman, A.; et al. A microfluidic optical platform for real-time monitoring of $\mathrm{pH}$ and oxygen in microfluidic bioreactors and organ-on-chip devices. Biomicrofluidics 2016, 10, 044111. [CrossRef] [PubMed]

309. Sticker, D.; Rothbauer, M.; Ehgartner, J.; Steininger, C.; Liske, O.; Liska, R.; Neuhaus, W.; Mayr, T.; Haraldsson, T.; Kutter, J.P.; et al. Oxygen Management at the Microscale: A Functional Biochip Material with Long-Lasting and Tunable Oxygen Scavenging Properties for Cell Culture Applications. ACS Appl. Mater. Interfaces 2019, 11, 9730-9739. [CrossRef] [PubMed]

310. Schneider, O.; Zeifang, L.; Fuchs, S.; Sailer, C.; Loskill, P. User-Friendly and Parallelized Generation of Human Induced Pluripotent Stem Cell-Derived Microtissues in a Centrifugal Heart-on-a-Chip. Tissue Eng. Part. A 2019, 25, 786-798. [CrossRef]

311. Vollert, I.; Seiffert, M.; Bachmair, J.; Sander, M.; Eder, A.; Conradi, L.; Vogelsang, A.; Schulze, T.; Uebeler, J.; Holnthoner, W.; et al. In vitro perfusion of engineered heart tissue through endothelialized channels. Tissue Eng. Part A 2014, 20, 854-863. [CrossRef] [PubMed]

312. Zhang, J. Engineered Tissue Patch for Cardiac Cell Therapy. Curr. Treat. Options Cardiovasc. Med. 2015, 17, 399. [CrossRef]

313. Shadrin, I.Y.; Allen, B.W.; Qian, Y.; Jackman, C.P.; Carlson, A.L.; Juhas, M.E.; Bursac, N. Cardiopatch platform enables maturation and scale-up of human pluripotent stem cell-derived engineered heart tissues. Nat. Commun. 2017, 8, 1825. [CrossRef] [PubMed]

314. Noor, N.; Shapira, A.; Edri, R.; Gal, I.; Wertheim, L.; Dvir, T. 3D Printing of Personalized Thick and Perfusable Cardiac Patches and Hearts. Adv. Sci. 2019, 6, 1900344. [CrossRef] [PubMed]

315. Dahlin, J.L.; Inglese, J.; Walters, M.A. Mitigating risk in academic preclinical drug discovery. Nat. Rev. Drug Discov. 2015, 14, 279-294. [CrossRef]

316. Raposo, V.L. Safe Drugs Versus Innovative Drugs (Can We Have Both?). Adv. Pharm. Bull. 2020, 10, 334-337. [CrossRef] [PubMed]

317. DiMasi, J.A.; Feldman, L.; Seckler, A.; Wilson, A. Trends in risks associated with new drug development: Success rates for investigational drugs. Clin. Pharm. Ther. 2010, 87, 272-277. [CrossRef] [PubMed]

318. Guo, L.; Abrams, R.M.; Babiarz, J.E.; Cohen, J.D.; Kameoka, S.; Sanders, M.J.; Chiao, E.; Kolaja, K.L. Estimating the risk of drug-induced proarrhythmia using human induced pluripotent stem cell-derived cardiomyocytes. Toxicol. Sci. 2011, 123, 281-289. [CrossRef] [PubMed]

319. Weaver, R.J.; Valentin, J.P. Today's Challenges to De-Risk and Predict Drug Safety in Human "Mind-the-Gap". Toxicol. Sci. 2019, 167, 307-321. [CrossRef] [PubMed]

320. Braam, S.R.; Passier, R.; Mummery, C.L. Cardiomyocytes from human pluripotent stem cells in regenerative medicine and drug discovery. Trends Pharm. Sci 2009, 30, 536-545. [CrossRef] [PubMed] 
321. Gwathmey, J.K.; Tsaioun, K.; Hajjar, R.J. Cardionomics: A new integrative approach for screening cardiotoxicity of drug candidates. Expert Opin. Drug Metab. Toxicol. 2009, 5, 647-660. [CrossRef] [PubMed]

322. Begley, C.G.; Ellis, L.M. Drug development: Raise standards for preclinical cancer research. Nature 2012, 483, 531-533. [CrossRef] [PubMed]

323. Vargas, H.M.; Bass, A.S.; Koerner, J.; Matis-Mitchell, S.; Pugsley, M.K.; Skinner, M.; Burnham, M.; Bridgland-Taylor, M.; Pettit, S.; Valentin, J.P. Evaluation of drug-induced QT interval prolongation in animal and human studies: A literature review of concordance. Br. J. Pharm. 2015, 172, 4002-4011. [CrossRef]

324. Toplak, Ž.; Hendrickx, L.A.; Abdelaziz, R.; Shi, X.; Peigneur, S.; Tomašič, T.; Tytgat, J.; Peterlin-Mašič, L.; Pardo, L.A. Overcoming challenges of HERG potassium channel liability through rational design: Eag1 inhibitors for cancer treatment. Med. Res. Rev. 2021, 42, 183-226. [CrossRef] [PubMed]

325. Cubeddu, L.X. Drug-induced Inhibition and Trafficking Disruption of ion Channels: Pathogenesis of QT Abnormalities and Drug-induced Fatal Arrhythmias. Curr. Cardiol. Rev. 2016, 12, 141-154. [CrossRef]

326. Johannesen, L.; Vicente, J.; Gray, R.A.; Galeotti, L.; Loring, Z.; Garnett, C.E.; Florian, J.; Ugander, M.; Stockbridge, N.; Strauss, D.G. Improving the assessment of heart toxicity for all new drugs through translational regulatory science. Clin. Pharm. Ther. 2014, 95, 501-508. [CrossRef] [PubMed]

327. Jung, C.B.; Moretti, A.; Mederos y Schnitzler, M.; Iop, L.; Storch, U.; Bellin, M.; Dorn, T.; Ruppenthal, S.; Pfeiffer, S.; Goedel, A.; et al. Dantrolene rescues arrhythmogenic RYR2 defect in a patient-specific stem cell model of catecholaminergic polymorphic ventricular tachycardia. EMBO Mol. Med. 2012, 4, 180-191. [CrossRef] [PubMed]

328. Witchel, H.J. Drug-induced hERG block and long QT syndrome. Cardiovasc. Ther. 2011, 29, 251-259. [CrossRef] [PubMed]

329. Rampe, D.; Brown, A.M. A history of the role of the hERG channel in cardiac risk assessment. J. Pharm. Toxicol. Methods 2013, 68, 13-22. [CrossRef]

330. Pointon, A.; Harmer, A.R.; Dale, I.L.; Abi-Gerges, N.; Bowes, J.; Pollard, C.; Garside, H. Assessment of cardiomyocyte contraction in human-induced pluripotent stem cell-derived cardiomyocytes. Toxicol. Sci. 2015, 144, 227-237. [CrossRef]

331. Sirenko, O.; Cromwell, E.F.; Crittenden, C.; Wignall, J.A.; Wright, F.A.; Rusyn, I. Assessment of beating parameters in human induced pluripotent stem cells enables quantitative in vitro screening for cardiotoxicity. Toxicol. Appl. Pharm. 2013, 273, 500-507. [CrossRef] [PubMed]

332. Blinova, K.; Stohlman, J.; Vicente, J.; Chan, D.; Johannesen, L.; Hortigon-Vinagre, M.P.; Zamora, V.; Smith, G.; Crumb, W.J.; Pang, L.; et al. Comprehensive Translational Assessment of Human-Induced Pluripotent Stem Cell Derived Cardiomyocytes for Evaluating Drug-Induced Arrhythmias. Toxicol. Sci. 2017, 155, 234-247. [CrossRef]

333. Reynolds, J.G.; Geretti, E.; Hendriks, B.S.; Lee, H.; Leonard, S.C.; Klinz, S.G.; Noble, C.O.; Lücker, P.B.; Zandstra, P.W.; Drummond, D.C.; et al. HER2-targeted liposomal doxorubicin displays enhanced anti-tumorigenic effects without associated cardiotoxicity. Toxicol. Appl. Pharm. 2012, 262, 1-10. [CrossRef] [PubMed]

334. Hnatiuk, A.P.; Briganti, F.; Staudt, D.W.; Mercola, M. Human iPSC modeling of heart disease for drug development. Cell Chem. Biol. 2021, 28, 271-282. [CrossRef]

335. Maizels, L.; Huber, I.; Arbel, G.; Tijsen, A.J.; Gepstein, A.; Khoury, A.; Gepstein, L. Patient-Specific Drug Screening Using a Human Induced Pluripotent Stem Cell Model of Catecholaminergic Polymorphic Ventricular Tachycardia Type 2. Circ. Arrhythmia Electrophysiol. 2017, 10, e004725. [CrossRef] [PubMed]

336. Knottnerus, S.J.G.; Mengarelli, I.; Wüst, R.C.I.; Baartscheer, A.; Bleeker, J.C.; Coronel, R.; Ferdinandusse, S.; Guan, K.; IJlst, L.; Li, W.; et al. Electrophysiological Abnormalities in VLCAD Deficient hiPSC-Cardiomyocytes Can Be Improved by Lowering Accumulation of Fatty Acid Oxidation Intermediates. Int. J. Mol. Sci. 2020, 21, 2589. [CrossRef]

337. Łoboda, A.; Dulak, J. Muscle and cardiac therapeutic strategies for Duchenne muscular dystrophy: Past, present, and future. Pharm. Rep. 2020, 72, 1227-1263. [CrossRef] [PubMed]

338. Shi, Y.; Inoue, H.; Wu, J.C.; Yamanaka, S. Induced pluripotent stem cell technology: A decade of progress. Nat. Rev. Drug Discov. 2017, 16, 115-130. [CrossRef] [PubMed]

339. Andrysiak, K.; Stępniewski, J.; Dulak, J. Human-induced pluripotent stem cell-derived cardiomyocytes, 3D cardiac structures, and heart-on-a-chip as tools for drug research. Pflügers Arch. Eur. J. Physiol. 2021, 473, 1061-1085. [CrossRef] [PubMed]

340. Gharanei, M.; Shafaattalab, S.; Sangha, S.; Gunawan, M.; Laksman, Z.; Hove-Madsen, L.; Tibbits, G.F. Atrial-specific hiPSC-derived cardiomyocytes in drug discovery and disease modeling. Methods 2021, 06, 1046-1060. [CrossRef] [PubMed]

341. Sharma, A.; McKeithan, W.L.; Serrano, R.; Kitani, T.; Burridge, P.W.; Del Álamo, J.C.; Mercola, M.; Wu, J.C. Use of human induced pluripotent stem cell-derived cardiomyocytes to assess drug cardiotoxicity. Nat. Protoc. 2018, 13, 3018-3041. [CrossRef]

342. Le, M.N.T.; Hasegawa, K. Expansion Culture of Human Pluripotent Stem Cells and Production of Cardiomyocytes. Bioengineering 2019, 6, 48-72. [CrossRef]

343. Kami, D.; Watakabe, K.; Yamazaki-Inoue, M.; Minami, K.; Kitani, T.; Itakura, Y.; Toyoda, M.; Sakurai, T.; Umezawa, A.; Gojo, S. Large-scale cell production of stem cells for clinical application using the automated cell processing machine. BMC Biotechnol. 2013, 13, 102. [CrossRef]

344. Zweigerdt, R.; Olmer, R.; Singh, H.; Haverich, A.; Martin, U. Scalable expansion of human pluripotent stem cells in suspension culture. Nat. Protoc. 2011, 6, 689-700. [CrossRef] [PubMed]

345. Kempf, H.; Kropp, C.; Olmer, R.; Martin, U.; Zweigerdt, R. Cardiac differentiation of human pluripotent stem cells in scalable suspension culture. Nat. Protoc. 2015, 10, 1345-1361. [CrossRef] 
346. Olmer, R.; Haase, A.; Merkert, S.; Cui, W.; Palecek, J.; Ran, C.; Kirschning, A.; Scheper, T.; Glage, S.; Miller, K.; et al. Long term expansion of undifferentiated human iPS and ES cells in suspension culture using a defined medium. Stem Cell Res. 2010, 5, 51-64. [CrossRef] [PubMed]

347. Wang, Y.; Chou, B.K.; Dowey, S.; He, C.; Gerecht, S.; Cheng, L. Scalable expansion of human induced pluripotent stem cells in the defined xeno-free E8 medium under adherent and suspension culture conditions. Stem Cell Res. 2013, 11, 1103-1116. [CrossRef] [PubMed]

348. Olmer, R.; Lange, A.; Selzer, S.; Kasper, C.; Haverich, A.; Martin, U.; Zweigerdt, R. Suspension culture of human pluripotent stem cells in controlled, stirred bioreactors. Tissue Eng. Part. C Methods 2012, 18, 772-784. [CrossRef]

349. Yang, H.S.; Jeon, O.; Bhang, S.H.; Lee, S.H.; Kim, B.S. Suspension culture of mammalian cells using thermosensitive microcarrier that allows cell detachment without proteolytic enzyme treatment. Cell Transplant. 2010, 19, 1123-1132. [CrossRef]

350. Kempf, H.; Olmer, R.; Kropp, C.; Rückert, M.; Jara-Avaca, M.; Robles-Diaz, D.; Franke, A.; Elliott, D.A.; Wojciechowski, D.; Fischer M.; et al. Controlling expansion and cardiomyogenic differentiation of human pluripotent stem cells in scalable suspension culture. Stem Cell Rep. 2014, 3, 1132-1146. [CrossRef] [PubMed]

351. Konagaya, S.; Ando, T.; Yamauchi, T.; Suemori, H.; Iwata, H. Long-term maintenance of human induced pluripotent stem cells by automated cell culture system. Sci. Rep. 2015, 5, 16647. [CrossRef] [PubMed]

352. Reinecke, H.; Zhang, M.; Bartosek, T.; Murry, C.E. Survival, Integration, and Differentiation of Cardiomyocyte Grafts. Circulation 1999, 100, 193-202. [CrossRef] [PubMed] 